\title{
37. SIGNIFICANCE OF LOWER PLIOCENE MASS-FLOW DEPOSITS FOR THE TIMING AND PROCESS OF COLLISION OF THE ERATOSTHENES SEAMOUNT WITH THE CYPRUS ACTIVE MARGIN ${ }^{1}$
}

\author{
Alastair H.F. Robertson ${ }^{2}$
}

\begin{abstract}
On the crestal area of the Eratosthenes Seamount at Site 966 an important "chaotic" interval composed of clast-rich, matrixsupported sediments (here named the Mass-Flow Unit) was recovered in five boreholes, situated up to $70 \mathrm{~m}$ apart. These sediments overlie shallow-water limestones of Miocene age and are, in turn, overlain by deep-water nannofossil ooze and sapropels of early Pliocene-Pleistocene age. Nannofossils and planktonic foraminifers indicate an early Pliocene age for the matrix, and a late Miocene to early Pliocene age for clasts within the Mass-Flow Unit. Clasts of shallow-water limestone and nannofossil chalk are both present. The matrix is mainly nannofossil ooze admixed with silt-sized reworked carbonate grains, minor quartz, and terrigenous clay. Whole-rock X-ray diffraction reveals variable quantities of calcite, dolomite, and aragonite, together with minor quartz and pyrite. Fibrous carbonate is seen in several thin sections. Limestone clasts have undergone extensive dissolution, followed by variable meteoric water cementation, presumably during Messinian emergence.

Comparable Miocene-Pliocene settings onshore in Cyprus are the following: (1) formation of lower Pliocene carbonate debris flows, similar to those at Site 966, related to extensional faulting; (2) Messinian erosion, karstification, and talus formation on the flanks of a graben undergoing active crustal extension during the late Miocene; (3) formation of deep channel and related debris flows of late Pliocene age. Of these, the first and second show similarities with the Eratosthenes Mass-Flow Unit. The Florence Rise also shows some similarities.

A depositional-tectonic model is proposed for the Site 966 Mass-Flow Unit, in which the Miocene limestone of Eratosthenes Seamount was subaerially exposed and diagenetically altered during the Messinian salinity crisis. This was followed by marine transgression and accumulation of lower Pliocene nannofossil ooze. Extensional faulting was active during the early Pliocene (and possibly earlier), resulting in subaqueous mass wasting of Miocene limestones and large-scale gravity reworking of nannofossil oozes as multiple debris flows. Tilting continued during emplacement of debris flows, resulting in interstratal shearing, slumping, and minor high-angle faulting.

Formation of the Mass-Flow Unit is interpreted to relate to the initial stages of collision of the Eratosthenes Seamount with the Cyprus active margin to the north. In this interpretation, the Eratosthenes Seamount was flexurally loaded by the advancing plate and underwent initial block faulting, followed by collapse and subsidence.
\end{abstract}

\section{INTRODUCTION}

Drilling during Leg 160 has documented subsidence of the Eratosthenes Seamount, from shallow water in the Miocene to much deeper water in the Pliocene-Pleistocene (Emeis, Robertson, Richter, et al., 1996). This subsidence is interpreted to relate to underthrusting of the Eratosthenes Seamount beneath an actively subducting margin to the north, of which Cyprus forms part (Limonov et al., 1994; Robertson et al., 1994, 1995b, 1995c; Fig. 1). The seamount forms part of the leading edge of the African plate, either as a marginal crustal block or promontory (Kempler, 1994; Robertson, 1995b). Distinctive "chaotic sediments" up to 70 m thick are located between Miocene shallow-water limestones and overlying Pliocene-Pleistocene deepsea hemipelagic sediments on the crest of the seamount at Site 966. The Shipboard Scientific Party suggested that these sediments (here termed the Mass-Flow Unit) were mainly formed by mass-flow processes in the early Pliocene, and this could provide important evidence of subsidence of the Eratosthenes Seamount (Emeis, Robertson, Richter, et al., 1996).

The aim of this paper is to describe and interpret the Mass-Flow Unit at Site 966. The discussion focuses on the sedimentary facies, petrography, and diagenesis of sediments recovered from four holes through the Mass-Flow Unit. Comparisons will also be made with

${ }^{1}$ Robertson, A.H.F., Emeis, K.-C., Richter, C., and Camerlenghi, A. (Eds.), 1998. Proc. ODP, Sci. Results, 160: College Station, TX (Ocean Drilling Program).

${ }^{2}$ University of Edinburgh, Department of Geology and Geophysics, West Mains Road, Edinburgh, EH9 3JW, United Kingdom. Alastair.Robertson@glg.ed.ac.uk three contrasting settings of Miocene-Pliocene tectonic-related sedimentation onshore in Cyprus, and with the lower Pliocene recovery from the Florence Rise to the west of Cyprus (Deep Sea Drilling Project [DSDP] Sites 375 and 376; Fig. 2). The information is then used to evaluate alternative interpretations of the genesis of the lower Pliocene Eratosthenes Mass-Flow Unit.

\section{TECTONIC SETTING}

Site 966 was selected for drilling, as it was an area of undisturbed Pliocene-Pleistocene sediments suitable for recovery of a wellpreserved suite of sapropels. The site was also intended to document the underlying pre-Pliocene succession. Shipboard site geophysical survey (Emeis, Robertson, Richter, et al., 1996) confirm the results of earlier north-south seismic profiling (Limonov et al., 1994) that revealed an upper nearly transparent interval of Pliocene-Pleistocene age. This is underlain by a regionally strong reflector ("M" reflector), interpreted as a late Miocene erosion surface. Both the PliocenePleistocene and the inferred underlying Miocene reflectors dip northward, reflecting mainly young (i.e., late Pleistocene) tectonics.

In the vicinity of Site 966, an east-west, single-channel seismic profile made by the JOIDES Resolution (Fig. 3) shows that the inferred "M" reflector locally exhibits a disrupted appearance over a distance of $\sim 2 \mathrm{~km}$ laterally. This reflector is also relatively weak, discontinuous, and slightly deeper than in adjacent areas, and can probably be correlated with the Mass-Flow Unit at Site 966. To the west of Site 966, a strong westward-dipping reflector underlies this diffuse " $\mathrm{M}$ " reflector. This is interpreted as the result of tectonic tilt of about $4^{\circ}$ to the west, of post-Miocene age. The seismic data, therefore, in- 


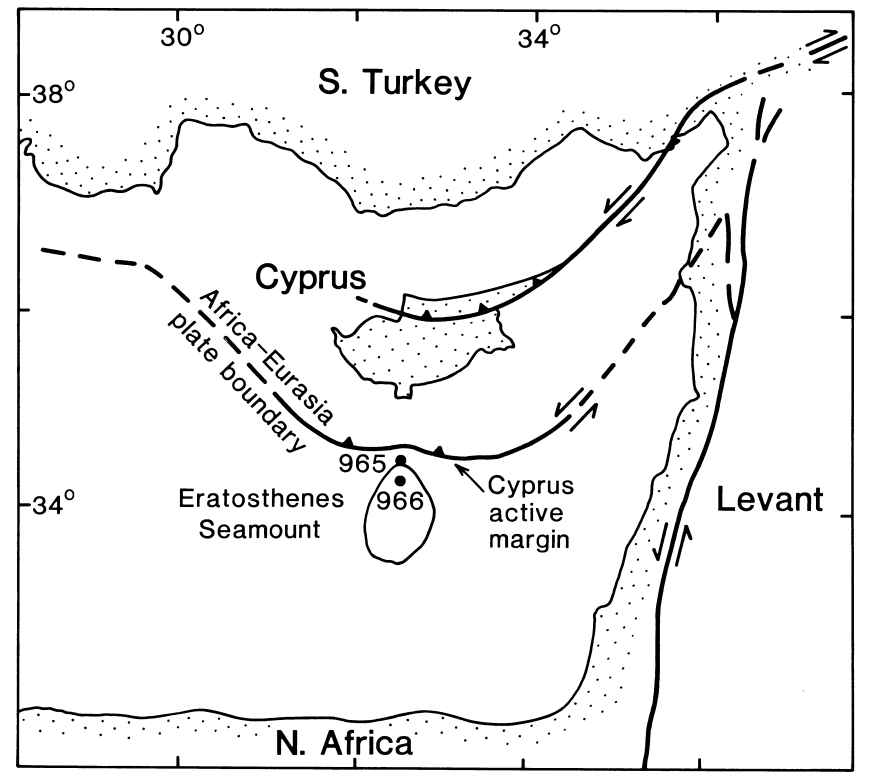

Figure 1. Location of Sites 965 and 966 on the Eratosthenes Seamount in relation to the tectonic setting of the Cyprus active margin.

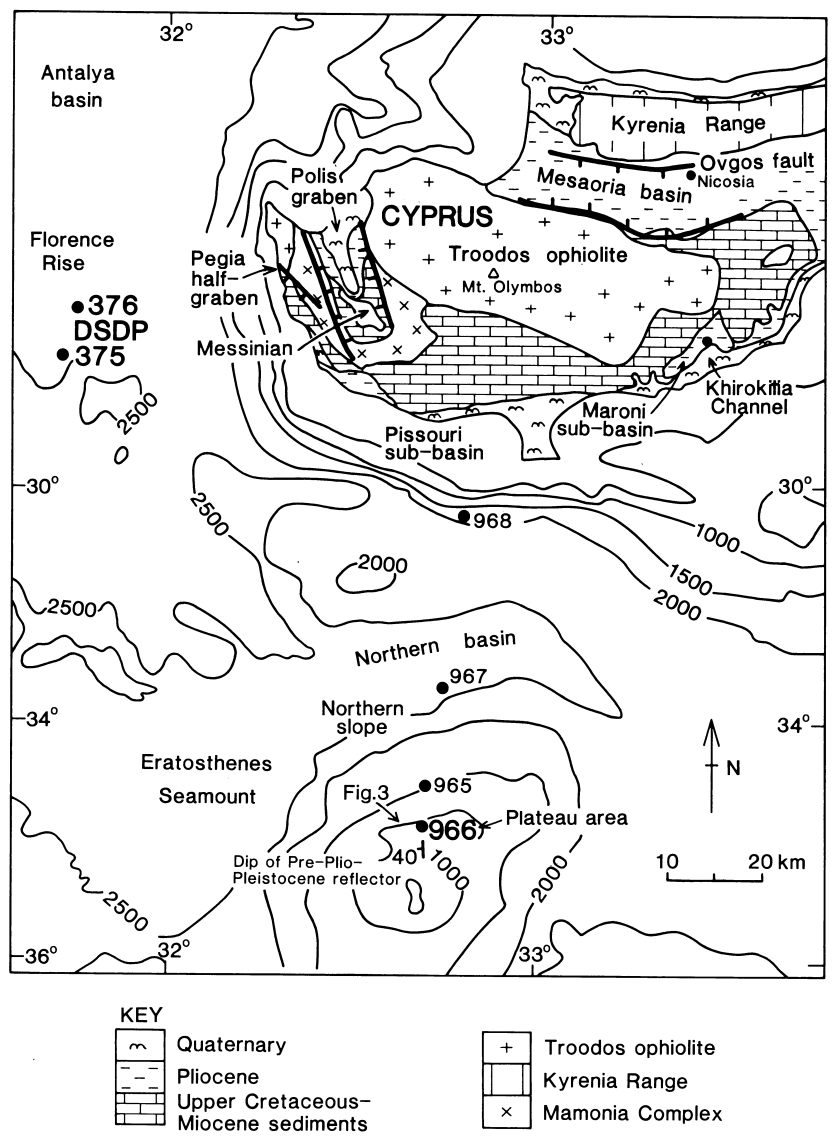

Figure 2. Locations of Sites 966 and 965 on the Eratosthenes Seamount in relation to the geology of southern Cyprus. Three comparable settings are discussed in Cyprus: (1) along the northern margin of the Troodos ophiolite (Mesaoria basin); (2) associated with the Polis graben in western Cyprus, and, (3) related to an upper Pliocene deep channel south of the Troodos (Khirokitia Channel, Maroni sub-basin).

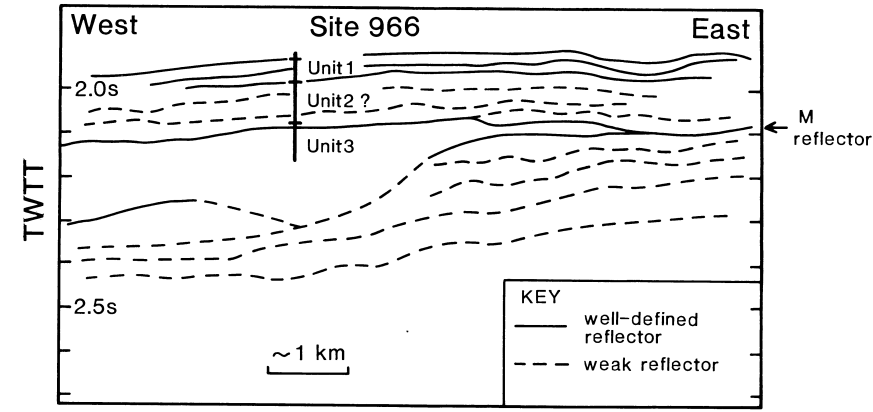

Figure 3. Sketch of seismic reflectors identified in the vicinity of Site 966 . The prominent Unit 2/Unit 3 boundary is interpreted as an upper Miocene erosion surface ("M" reflector). Note the weakly defined dipping reflectors beneath. These may relate to late Miocene erosion or deformation of Eratosthenes. See text for further explanation. TWTT $=$ two-way traveltime.

dicate that tectonic tilting in the vicinity of Site 966 occurred before development of the Pliocene-Pleistocene succession, which itself was tilted northward at a late stage. This early tectonic tilting could be relevant to formation of the Mass-Flow Unit, as discussed later.

\section{STRATIGRAPHIC SETTING}

The Mass-Flow Unit was recovered at Site 966 on a relatively elevated fault-bounded block on the northern part of the Eratosthenes Seamount plateau area. By contrast, at Site 965 on the upper northern slopes of the seamount, the interval between shallow-water Miocene limestone and overlying Pliocene-Pleistocene deep-sea sediment is restricted to $<10 \mathrm{~m}$ of calcareous clays with caliche (Emeis, Robertson, Richter, et al., 1996).

The Mass-Flow Unit was recovered in four holes (Holes 966A, 966B, 966C, and 966D) recovered by hydraulic piston coring and advanced piston coring techniques; one hole was cored by rotary drilling (Hole 966F). The top of the unit can be correlated between the holes based on the first appearance of matrix-supported, clast-rich sediments below more uniform nannofossil oozes and sapropels. The base of the unit is more difficult to determine because of poor recovery and the fact that many of the clasts in the lower part of the MassFlow Unit are similar to the underlying Miocene shallow-water limestones. Where recovery was minimal, it is almost impossible to distinguish between clasts derived from the Mass-Flow Unit and clasts created by drilling disturbance of underlying Miocene limestone. However, the log data from Hole 966F (especially the formation microscanner [FMS] data) indicate a clear difference between the overlying clast-rich Mass-Flow Unit and the more uniform underlying Miocene limestones. During the shipboard study, the lower boundary of the Mass-Flow Unit (i.e., lithostratigraphic Unit 2) was set, based on the first recovery of clasts of mainly shallow-water limestones assumed to belong to the underlying Miocene succession (i.e., lithostratigraphic Unit 3). However, post-cruise petrographic study shows that some of these clast-rich intervals include a pelagic matrix similar to that of the overlying Mass-Flow Unit, but which is not present in the underlying Miocene limestone. As a result, the base of the MassFlow Unit is now inferred to lie below the recovered intervals in Holes 966A, 966B, 966C, and 966D (Fig. 4).

The analysis of conventional logs and FMS images of Hole $966 \mathrm{~F}$ indicate that the contact between the Mass-Flow Unit and the underlying Miocene limestone is located at $114 \mathrm{~m}$ below seafloor (mbsf) (Emeis, Robertson, Richter, et al., 1996; Major et al., Chap. 38, this volume). The FMS images of the Mass-Flow Unit appear as a lowresistance unit, with scattered large clasts exceeding $10 \mathrm{~cm}$ in diameter. The overall abundance of clasts increases downward in Hole 966F. Gamma-ray logs indicate the presence of small amounts of 


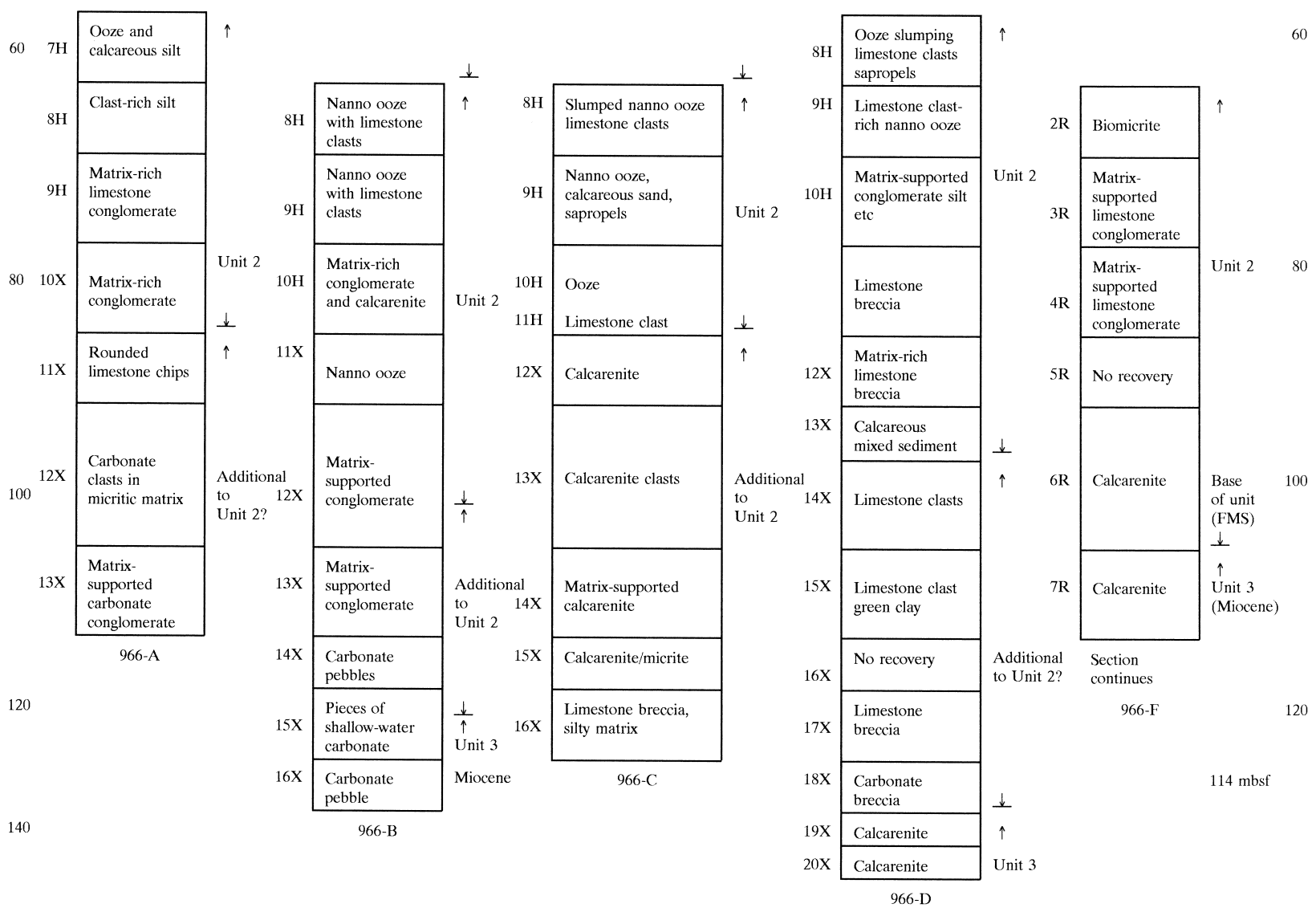

Figure 4. Summary of the cored intervals of the lower Pliocene Mass-Flow Unit at Site 966. (Note: these are generalized.) The top of the Mass-Flow Unit is defined as is the first evidence of reworked limestone clasts in a fine-grained matrix. The base of the Mass-Flow Unit is placed where uniform shallow-water Miocene limestones first begin. The upper boundary is that identified in Emeis, Robertson, Richter, et al. (1996). However, petrographic studies indicate that the base of the Mass-Flow Unit should be positioned lower than previously placed within Holes 966A, 966B, 966C, and 966D. In addition, the base of the MassFlow Unit is repositioned in Hole $966 \mathrm{~F}$ based on FMS data.

clay, whereas an isolated strong peak in uranium at about $89.5 \mathrm{mbsf}$ appears to correlate with a disturbed organic-rich interval in Section 160-966F-4R-1 (Major et al., Chap. 38, this volume). In addition, the Mass-Flow Unit in Hole $966 \mathrm{~F}$ is inferred to be markedly dipping and cut by a fault.

\section{BIOSTRATIGRAPHY}

Within the recovered intervals of the Mass-Flow Unit, nannofossils are low in abundance, commonly poorly preserved, and have calcite overgrowths (Emeis, Robertson, Richter, et al., 1996). However, one sample (Sample 160-966A-10X-CC) from the lower part of the unit contains a diverse nannofossil assemblage indicative of Zone NN12. Chalk clasts and matrix from higher in the overall succession (Core 160-966F-3R) contain Reticulofenestra rotaria, which is believed to occur only in the lower part of the Messinian stage (Theodiridis, 1984), implying that the host breccia is younger than early Messinian. Another sample from higher in the overall succession (Sample 160-966F-1R-CC) contains a nannofossil assemblage diagnostic of Zone NN13. Planktonic foraminifers provide little additional information, except that one sample (Sample 160-966A-13H-CC) contains rare specimens of Globorotalia margaritae, together with Sphaeroidinellopsis. This means that the sediment can be attributed to a very extended interval containing both $G$. margaritae and Sphaeroidinellopsis sp. (i.e., from Zone MPL1 to MPL3 where these two groups occur together). However, as the last sample with good age control (Sample 160-966A-7H-CC) is within MPL2, the interval with G. margaritae can be restricted to MPL1-MPL2 (S. Spezzaferri, pers. comm., 1996).

\section{LITHOSTRATIGRAPHY}

The main features of the sedimentary succession recovered within the Mass-Flow Unit within each borehole are now summarized (Fig. $5)$.

\section{Hole 966A}

The Mass-Flow Unit in Hole 966A begins with recovery of a single, well-rounded, limestone pebble ( $\sim 5 \mathrm{~cm}$ in diameter). Recovery of the overlying $30 \mathrm{~m}$ is restricted to small micritic limestone clasts set in a micritic matrix, and scattered rounded limestone clasts $(<2$ $\mathrm{cm}$ in diameter). The upper part of the succession in Hole 966A comprises matrix-supported rudites, with minor intercalations of calcareous sand and calcareous mud. This then passes into nannofossil ooze, with only scattered small carbonate clasts.

\section{Hole 966B}

The lower part of the succession is dominated by matrix-supported calcirudites, overlain by nannofossil ooze, with scattered small $(<2 \mathrm{~cm})$ carbonate clasts. The higher part of the succession in Hole 


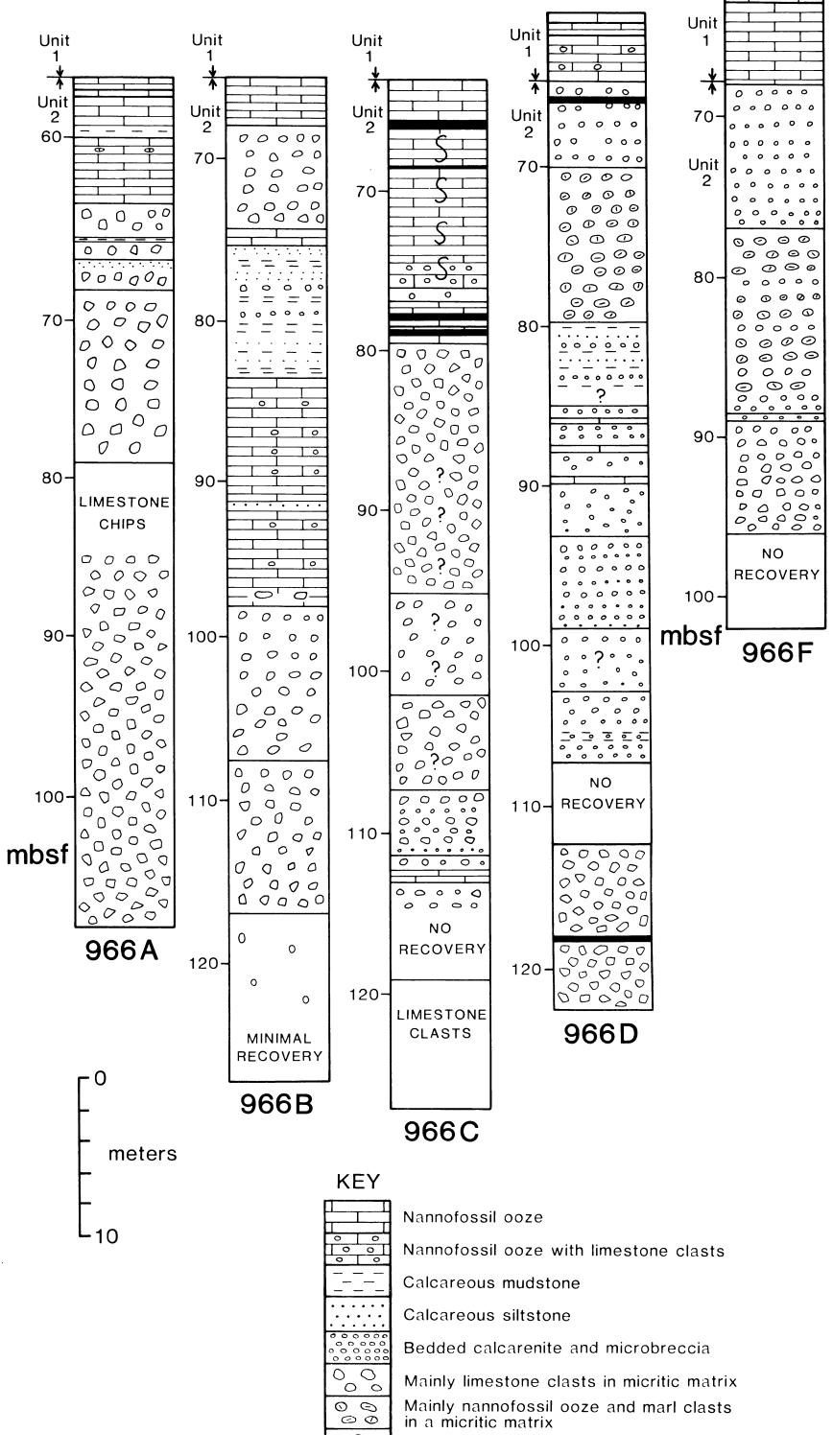

Figure 5. Summary logs of the Mass-Flow Unit successions recovered from Site 966 on the Eratosthenes Seamount plateau area. The logs are generalized from variable recovery. See text for discussion.

966 B includes calcareous muds, silts, and sands interbedded with uncemented fine calcirudites. A unit of matrix-supported calcirudites follows and is finally overlain by nannofossil ooze.

\section{Hole 966C}

Recovery in the lower part of the unit is limited to minor matrixsupported calcirudites. Thin $(<1 \mathrm{~m})$ intercalations of nannofossil ooze and layered fine calcirudites occur near the base. The higher part of the succession includes several meters of nannofossil oozes with interbedded sapropels. The uppermost levels are dominated by nannofossil oozes that dip at variable angles and show evidence of contorted bedding and slumping.

\section{Hole 966D}

The lowest part of the unit recovered includes interbedded mudstones, nannofossil ooze, and layered fine calcirudites. The succession above is dominated by matrix-supported calcirudites. Clasts lower in this succession are commonly composed of well-cemented limestone, whereas those higher up are mainly composed of calcareous mudstone and impure micrite. The unit ends in nannofossil ooze, with scattered carbonate clasts and several sapropels.

\section{Hole 966F}

The recovery is mainly matrix-supported calcirudites. Clasts lower in the succession are commonly limestone, whereas those in the middle and higher levels of the succession are mainly calcareous mud and marl.

Taking the five drilled successions together, a number of generalizations can be made:

1. No intact contact is preserved with the underlying Miocene shallow-water limestones. A well-rounded fluvial pebble in Hole 966A could have been located near the unconformity surface.

2. The lower part of the unit is dominated by massive or weakly stratified matrix-supported sediments, in which numerous well-cemented clasts (i.e., limestone) are present. Some of these are relatively well rounded.

3. The middle part of the unit is dominated by matrix-supported sediments in which most of the clasts are unlithified micrite, weakly lithified chalk, or calcareous mud; most are subangular to angular.

4. The higher levels of the unit contain intercalations of wellstratified nannofossil ooze, calcareous muds, carbonate sand, and fine calcirudite. By contrast, matrix-supported calcirudite is more abundant in Hole 966F.

5. The uppermost levels of the unit are mainly nannofossil ooze, with only scattered small (i.e., several centimeters) carbonate clasts (mainly poorly lithified) and rare sapropels.

6. The sediments pass upward over a short interval (i.e., tens of centimeters) into nannofossil oozes, muds, and sapropels characteristic of the overlying Pliocene-Pleistocene succession.

When the successions in the four holes drilled are plotted in their relative positions, an overall trend is apparent (Fig. 6). The most northerly site (Hole 966A) contains the most evidence of coarse limestone breccia with relatively little matrix, whereas the more southerly sites have relatively more interbedded finer grained sediments, including calcareous sands, muds, and sapropels (especially Hole 966B). However, the information is insufficient to make any assumptions about provenance.

\section{Role of Drilling Disturbance}

The unit is dominated by chaotic matrix-supported, "soupy" sediments, commonly without any trace of bedding. One possibility considered by the Shipboard Scientific Party was that these chaotic sediments were the result of drilling disturbance and "suck in" (i.e., suction of sediment from the bottom of the hole into the core). Drilling disturbance can result where layers of hard and soft rock are interbedded, such that the hard layers break into fragments and are mixed with softer material. "Suck in" may occur when drilling is impeded (e.g., by a hard layer); material that has fallen down the hole is then re-cored and could be mistaken for a true sedimentary mass-flow deposit. 


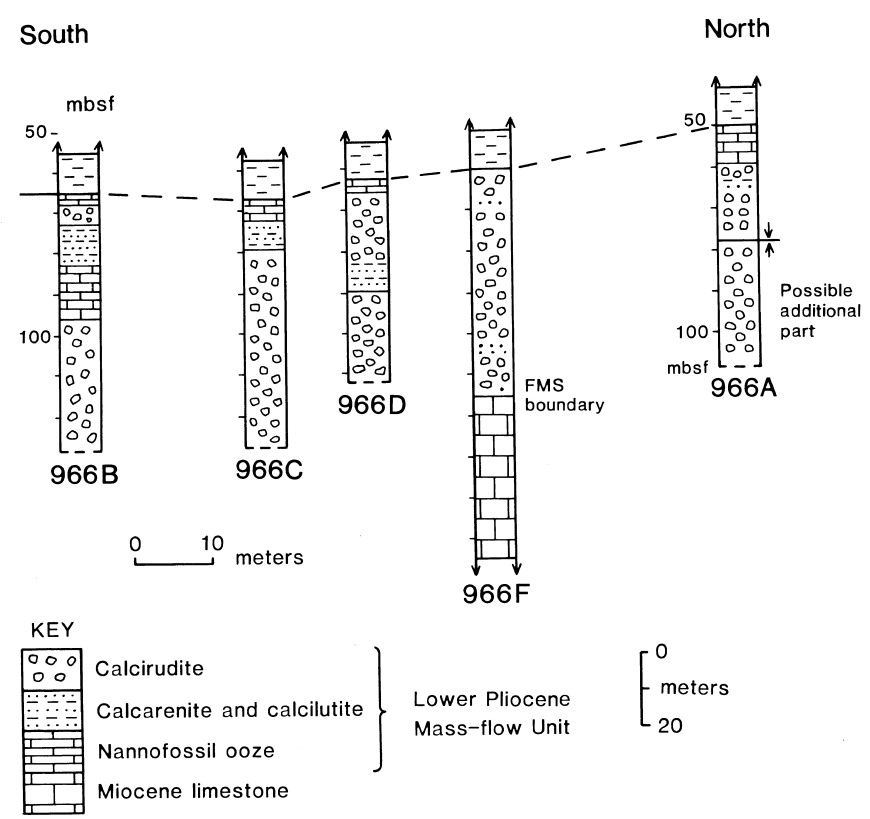

Figure 6. Relative locations of holes drilled at Site 966. Note the relative thicknesses of the lower Pliocene Mass-Flow Unit in each hole. See text for discussion. The base of lithostratigraphic Unit 2 in Hole 966F was recorded in Emeis, Robertson, Richter, et al. (1996) as at 60 mbsf. However, this followed a mistake on the Core Description Form; the correct location of the base is at $68.0 \mathrm{mbsf}$.

Several lines of evidence indicate that the mass-flow deposits are certainly of primary origin (although intervals of "suck in" and other drilling disturbance are undoubtedly present):

1. Where visible, the sedimentary layering, including fine lamination, is generally subhorizontal. This contrasts with "suck in" material that typically has a vertical pseudolayering (e.g., Core 160-966D-10H).

2. Locally preserved color banding records oxidation-reduction boundaries of diagenetic origin that could not have survived drilling disturbance or "suck in."

3. Especially in the lower levels of the succession, some of the matrix-supported, clast-rich sediments are moderately indurated and locally cemented by sparry calcite, which rules out an origin related to drilling disturbance.

4. The Mass-Flow Unit was clearly imaged by the FMS, and the results are interpreted as indicating the presence of clasts in a matrix (Major et al., Chap. 38, this volume).

\section{LITHOFACIES}

Detailed lithologic logs of representative parts of the succession within the Mass-Flow Unit are shown in Figures 7 and 8. The recognized lithofacies are described below.

\section{Nannofossil Ooze}

Minor intercalations occur throughout and dominate the highest levels, transitional to the Pliocene-Pleistocene succession. The nannofossil oozes are typically white to off white or pale gray and contain local concentrations of planktonic foraminifers. Near the top of the unit, the oozes are slightly gritty because of the presence of sandsized carbonate particles and contain minor disseminated sulfide material.

\section{Sapropels}

Minor sapropels are present. Rare intact sapropels are mainly burrowed and unlaminated (e.g., Core 160-966C-9H). Several sapropels are contorted (e.g., Cores 160-966D-8H-10H), or streaked out parallel to bedding (e.g., Core 160-966D-18X). Several individual sapropels contain small $(<1 \mathrm{~cm})$ limestone fragments (e.g., Core 160966D-18X).

\section{Calcareous Mudstones}

Greenish or brownish finely laminated calcareous mudstones are present as thin $(<5 \mathrm{~cm})$ interlayers (e.g., Cores 160-966A-8H, 966B$8 \mathrm{H}$, and $966 \mathrm{D}-18 \mathrm{X}$ ), as a matrix to clasts, and are commonly associated with organic-rich laminae. The mudstones commonly contain calcareous silt (e.g., Core 160-966B-9H). Calcirudite is locally observed above green calcareous mudstone, associated with disruption of laminae and development of small-scale flame structures $(<5 \mathrm{~mm})$. Ash particles are seen near the top of the succession within a $720-\mathrm{cm}-$ thick interval (Core 160-966D-8H).

\section{Calcareous Siltstones and Sandstones}

Relatively rare intervals of crudely stratified coarse carbonate sand, or fine calcirudite are present. Normal grading over several centimeter-thick intervals is locally present (e.g., Core 160-966B-9H), and some of the sediments are probably turbiditic. Carbonate sand ranges from unconsolidated (e.g., Core 160-966B-9H) to relatively well cemented. Alternations of calcareous mud, carbonate silt, and fine sand are also present (e.g., Core 160-966D-12DX). The carbonate sand is mostly composed of bioclastic material, including shell and echinoderm fragments. In addition, rare thin layers of foraminiferal sand also occur within nannofossil ooze, especially higher in the succession (e.g., Core 160-966C-8H).

\section{Matrix-Supported Clast-Rich Sediments}

Two types of matrix-supported clast-rich sediments occur either separately or are intergradational with chalk clasts or with limestone clasts.

\section{Matrix-Supported Sediments with Nannofossil Chalk Clasts}

These typically form intervals of massive to weakly stratified sediment (up to one meter thick or more) comprised of mainly subangular clasts of weakly cemented nannofossil ooze (i.e., chalk) in a pale micritic matrix or locally muddy matrix (Fig. 9C). Subordinate limestone clasts are also present within individual nearly massive units (Fig. 9A). For example, clasts, especially in the upper part of the succession, are mainly micritic, but also contain scattered small angular limestone fragments ( $<1 \mathrm{~cm}$ in size). Vague color banding, mottling, and bioturbation are commonly observed, especially higher in the succession (e.g., Cores 160-966C-8H and 966D-8H).

\section{Matrix-Supported Sediments with Limestone Clasts}

These are more common in the lower part of the succession. In detail, clasts range from angular (e.g., Cores 160-966B-9H and 966D18X; Fig. 9B), to subrounded (Core 160-966B-9H), to rarely rounded (e.g., Core $160-966 \mathrm{~F}-2 \mathrm{R}$ ). Most clasts range from 1 to $2 \mathrm{~cm}$ in size 
Figure 7. Detailed logs of selected intervals of the MassFlow Unit, illustrating the primary depositional interbedding.
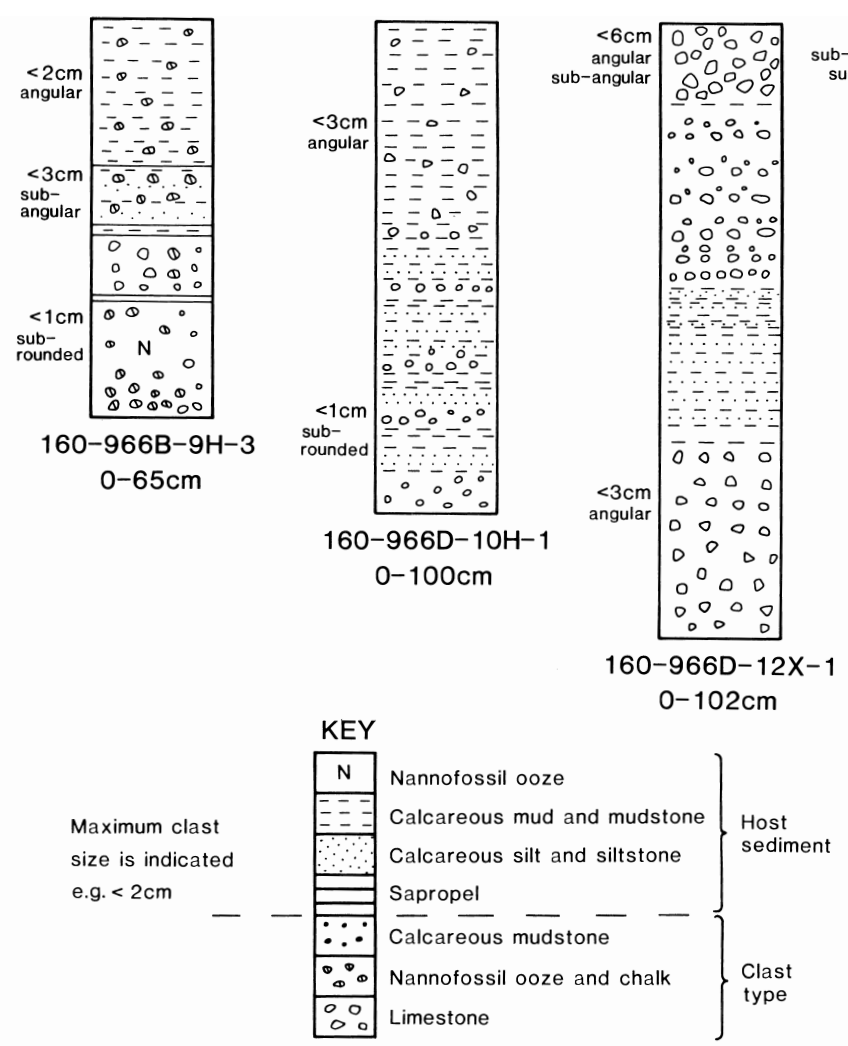

(e.g., Core 160-966B-9H), but locally reach $3-5 \mathrm{~cm}$. The clasts are mainly limestone, defined as well-cemented carbonate. Occasional clasts of muddy carbonate (Core 160-966B-10X), fine to coarse carbonate sand, and calcirudite (Core 160-966B-9H) are also present. In several instances (e.g., Core 160-966F-3R), calcirudite clasts are very finely laminated. Fragments of replacement chert were noted in one case (Core 160-966F-2R).

The matrix is mainly fine-grained nannofossil ooze, but is locally composed of carbonate sand (Core 160-966B-9H) or silty clay (Core 160-966D-8H). Concentrations of planktonic foraminifers shells are locally observed (e.g., Core 160-966C-8H). Cementation varies within individual depositional units (e.g., Core 160-966F-3R); several thin intervals are moderately well cemented, with unusually wellrounded clasts, set in an indurated, calcareous mud matrix.

Individual intervals rich in limestone clasts range from centimeter-thick beds (e.g., Core 160-966C-9H) to several meter-thick units of massive (e.g., Core 160-966B-8H), crudely stratified (e.g., Core $160-966 \mathrm{D}-9 \mathrm{H}$ ), or weakly normally size-graded units (Core 160966D-12X). Clasts are commonly angular to subangular (e.g., Cores 160-966A-8H and 966D-9H), but are locally subrounded (e.g., Cores 160-966B-9H and 966A-11X) and rarely well rounded (e.g., 966B$10 \mathrm{H}$ and $966 \mathrm{~A}-13 \mathrm{X}$ ). The clasts commonly range in size from 1 to 5 $\mathrm{cm}$ (Cores 160-966B-9H and 966D-10H), but exceptionally reach 9$10 \mathrm{~cm}$. Clast lithologies range from calcilutite (Cores 160-966A-7H and 966B-10H), to calcisiltite (Core 160-966C-16X), calcarenite (packstone/grainstone textures) (Cores $160-966 \mathrm{C}-11 \mathrm{H}$ and $12 \mathrm{H}$ ), veined crystalline limestone (e.g., Cores 160-966X-8B and 9C), to porous, diagenetically altered, coralline limestone (e.g., Cores 160966B-9H, 11X, and 966D-9H) and dolomite (Core 160-966X-16C). Fossils observed include shell fragments (Core 160-966C-9H), calcareous algae, and gastropods. Rare clasts of brown, poorly lithified material were identified by X-ray diffraction as opal. The matrix of the calcirudite is commonly micritic, but is rarely composed of medium- to coarse-grained carbonate sand (e.g., Core 160-966B-9H). In 


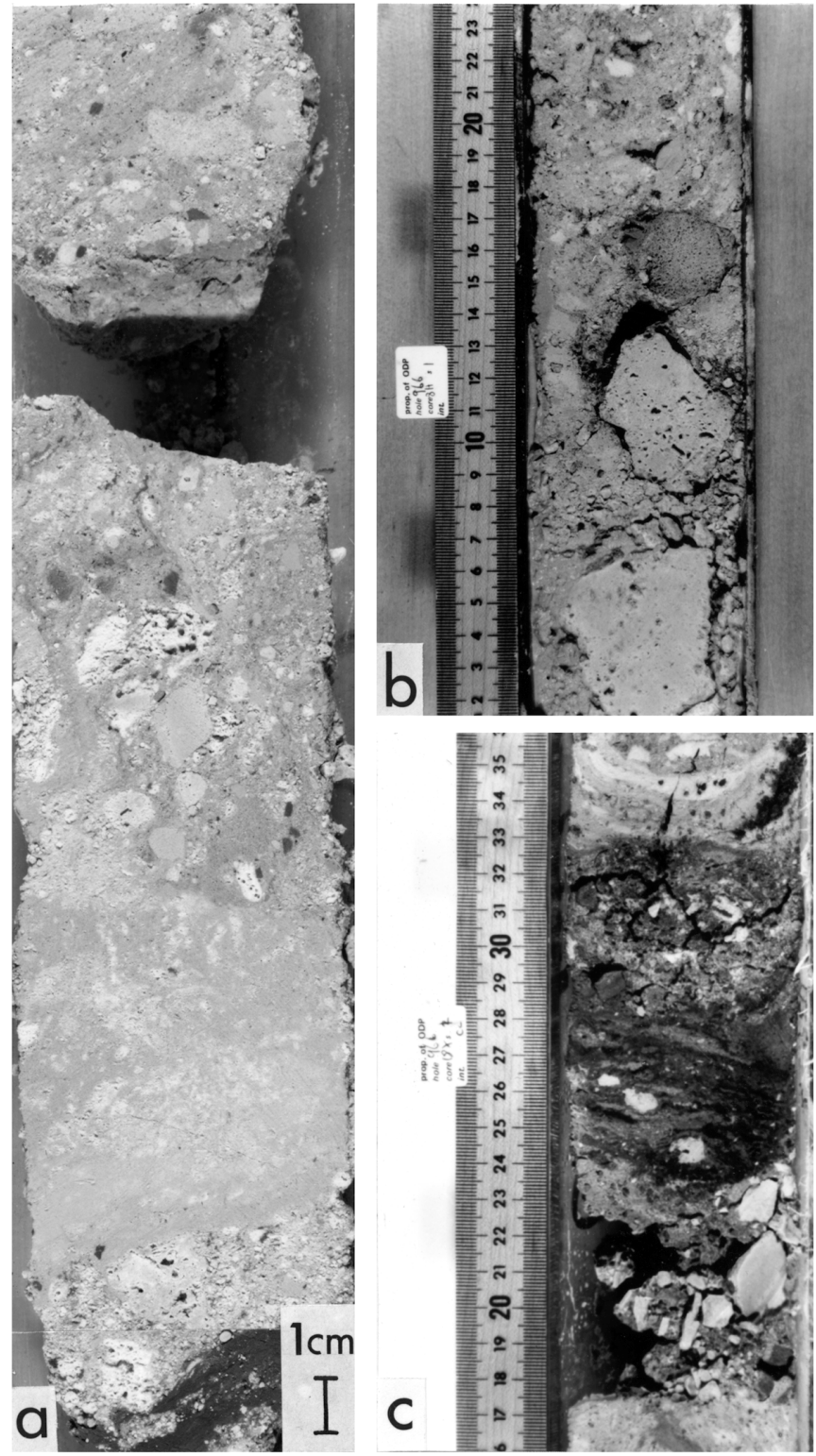

Figure 9. Core photographs of the Mass-Flow Unit. A. Typical carbonate debris flow. Note the matrix-supported fabric, interval 160-966F-4R-1, 8-32 $\mathrm{cm}$. B. Debris flow with porous angular clasts of Miocene shallow-water carbonate, interval 160-966A-8H-1, 2-24 cm. C. Debris flow with interbedded dark muddy carbonate, interval 160-966D-18X-CC. See text for further discussion.

several short intervals (e.g., Core 160-966C-13X) within the lower part of the unit, large angular fragments of calcarenite to calcirudite are subrounded to rounded (up to $5 \mathrm{~cm}$ in size), and set in a coarse bioclastic matrix (e.g., Core 160-966D-19X). Several of these clasts were already partly disaggregated when deposited (e.g., Core 160966D-9H).

\section{Clast-Supported Conglomerates and Breccias}

Clast-supported textures are very subordinate relative to matrixsupported fabrics, but where present tend to form discrete intervals within thicker matrix-supported units. Clast-supported fabrics are also locally seen near the base of the succession where recovery was minimal. Two contrasting types of coarse-grained clast-supported redeposited carbonates are present: (1) clasts of poorly lithified nannofossil ooze (i.e., chalky), and (2) limestone clasts. In general, limestone clasts are more abundant in the lower part of the unit, whereas clasts of nannofossil ooze and chalk predominate higher in the overall succession. Subordinate matrix is mainly composed of nannofossil ooze and clay-rich micrite. Recovery of the clast-supported limestones was very poor, and distinction from Miocene limestone fragmented by drilling is not always clear.

\section{PETROGRAPHY}

Twenty-six samples of clasts and matrix were studied under the optical microscope.

\section{Clasts}

Several clasts are composed of moderately well cemented chalk with poorly preserved planktonic foraminifers (e.g., interval 160966B-9H-4, 103-106 cm). Angular to subrounded clasts of finegrained chalk in the upper part of the succession comprise recrystallized micrite, with traces of bioclasts (interval 160-966A-7H-6, 86$90 \mathrm{~cm}$ ). One calcilutite clast is peloidal (intervals $160-966 \mathrm{~A}-9 \mathrm{H}-2$, $45-49 \mathrm{~cm}$, and $966 \mathrm{~B}-9 \mathrm{H}-4,26-31 \mathrm{~cm}$ ) with phosphatic grains, another is rich in small shell fragments (interval 160-966A-9H-1, 0-3 $\mathrm{cm})$. Other clasts of fine pelletal calcilutite include ostracods and rare benthic foraminifers (interval 160-966B-14X-CC, 0-18 cm). Some other clasts are diagenetically little altered and contain small shell fragments, echinoderm plates, and micritic clasts.

By contrast, limestone clasts are mainly of shallow-water origin, similar to the underlying Miocene cored interval. Individual clasts of poorly sorted bioclastic limestone contain calcareous red algae (interval 160-966C-13X-1, 10-14 cm), coral (interval 160-966C-15X-CC, $7-10 \mathrm{~cm}$ ), bryozoans (interval 160-966D-15X-CC, 0-5 cm), echinoderms, shell fragments (Fig. 10C), and phosphatic grains (interval 160-966C-13X-1, 25-27 cm). Other lithologies include packstone composed of well-sorted and well-rounded allochems including shell fragments, benthic foraminifers, echinoderm plates, phosphatic grains, calcareous red algal fragments, and numerous intraclasts of pelagic carbonate (interval 160-966D-12X-4, 93-95 cm; Figs. 11A$11 \mathrm{~F})$.

\section{Matrix}

In thin section, the matrix commonly has a microbreccia appearance, with small $(<0.1 \mathrm{~mm})$ angular to subrounded micritic clasts set in a partly recrystallized micritic matrix (e.g., interval 160-966D$10 \mathrm{H}-1,102-109 \mathrm{~cm})$. Planktonic foraminifers, benthic foraminifers, and small shell fragments are locally abundant (e.g., interval 16096B-14X-CC, 0-18 cm; Fig. 10F). The matrix commonly resembles some of the less-cemented clasts, described above.

\section{SEDIMENTARY STRUCTURES}

The main sedimentary structures (Figs. 7,8 ) are parallel lamination in fine-grained facies, normal grading in calcareous silts, sands, and fine calcirudites (e.g., Core 160-966B-9H), and weakly developed normal grading in some matrix-supported clast-rich sediments. In addition, an up to 6-m-thick interval noted in one hole (i.e., Core 160-966X-8C) exhibits inclined and contorted lamination and disturbed Zoophycos burrows; this is interpreted as a major slump. Other thinner, contorted units (e.g., $30 \mathrm{~cm}$ thick in Core 160-966D-9H) are envisioned as small slumps. Rare convolute laminated units (e.g., Core $160-966 \mathrm{C}-8 \mathrm{H})$ reflect slumping and/or dewatering. 

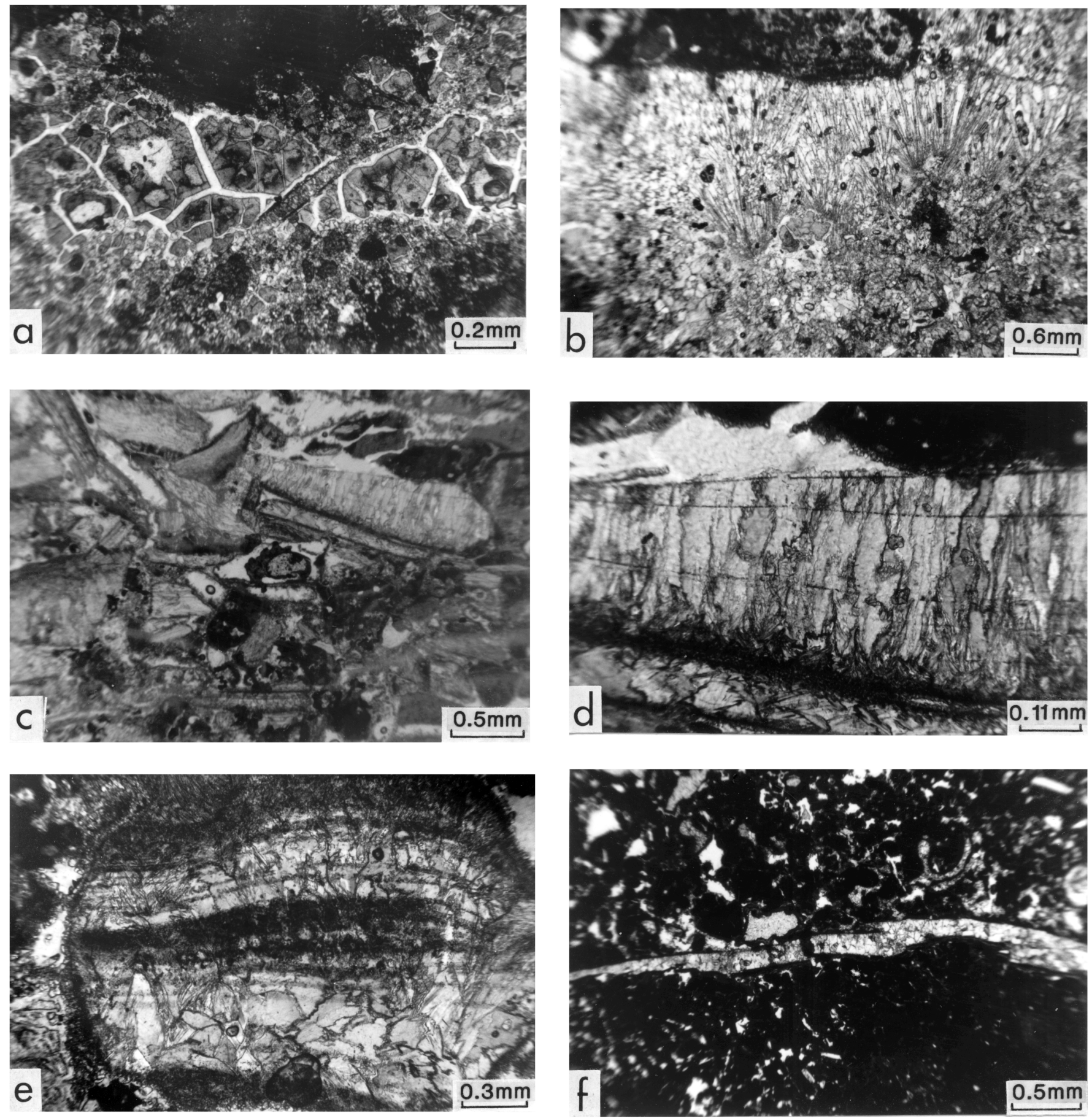

Figure 10. Photomicrographs of clasts. A. Limestone fragment within debris flow containing areas of fibrous carbonate (central band) (interval 160-966C-13X$1,40-43 \mathrm{~cm}$ ). B. Limestone fragment within another debris flow containing fibrous carbonate grains. Whole-rock X-ray diffraction revealed aragonite as well as calcite in both A and B; thus the fibrous carbonate is probably a remnant of aragonite of early diagenetic origin (interval 160-966C-13X-1, 10-14 cm). C. Limestone clast in debris flow. This is a packstone with numerous broken and abraded shell fragments. Micritic envelopes developed, then the shell interiors dissolved and were replaced by prismatic sparry calcite. The mainly micritic matrix was largely dissolved and partly filled with sparry calcite interval (interval 160 966A-13X-CC, 1-4 cm). D. Detail of C. Note the micritic envelope and post-dissolution sparry calcite fill. E. Same section as C. Note that the shell fragment was broken (related to reworking) and then developed a micritic envelope before internal dissolution. F. Detail of a limestone pebble. This is pelletal limestone with thin-walled shell fragments (bivalves?). The shell shows evidence of early breakage (resulting from compaction?), followed by internal reprecipitation and fill with sparry calcite (interval 160-966B-14X-CC, 16-18 cm). 

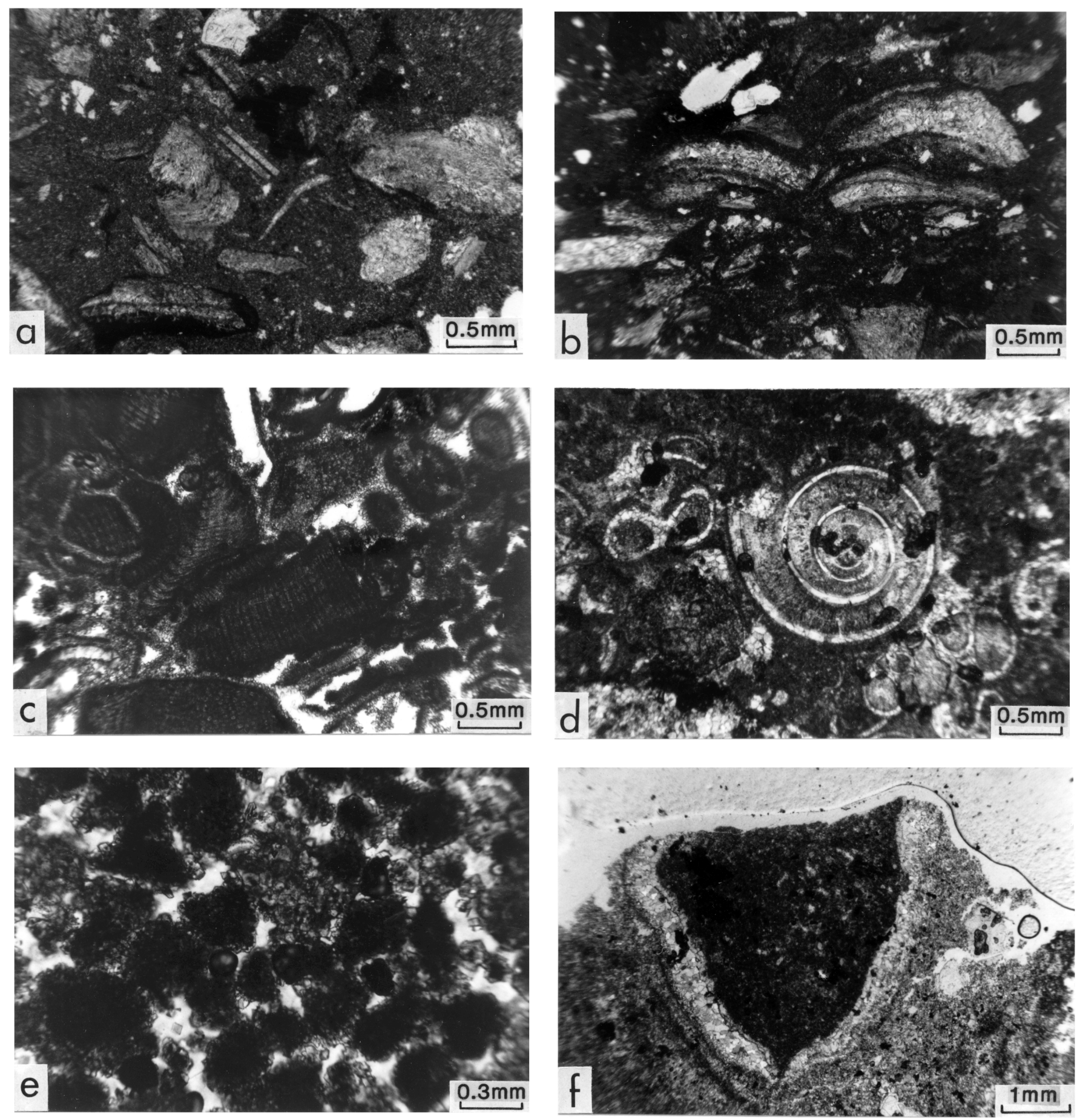

Figure 11. Photomicrographs of clasts. A. Biomicrite with angular broken fragments of bivalve shells and other allochems. Unrecrystallized micrite and bivalve shells are an unusual feature, as Miocene limestones were exposed to meteoric water diagenesis in the Messinian and this sediment may thus be of early Pliocene age (i.e., of post-transgression origin) (interval 160-966C-12X-CC, 12-14 cm). B. Clast of muddy micrite with numerous broken and abraded bivalve shell fragments. The shell fragments are only partially recrystallized to sparry calcite, whereas the matrix is mainly unrecrystallized (interval $160-966 \mathrm{C}-12 \mathrm{X}$ CC, 12-14 cm). C. Biomicrite clasts composed of broken, reworked fragments, mainly calcareous algae in a micritic matrix. The matrix was partly dissolved, probably during the Messinian salinity crisis (interval 160-966B-9H-4, 26-31 cm). D. Small gastropod shells with sparry calcite cement fill within biomicrite that includes planktonic foraminifers; clast within debris flow (interval 160-966C-16X-CC, 8-10 cm). E. Pelletal micrite with micrite between pellets preferentially dissolved, followed by minor calcite spar precipitation (Section 160-966C-16X-CC). F. Biomicrite intraclast within calcisiltite; intraclast surrounded by sparry calcite (interval 160-966D-19X-CC, 20-21 cm). 


\section{TECTONIC STRUCTURES}

Occasional, mostly planar, high-angle faults and several small reverse faults were noted (e.g., Cores 160-966C-8H-1 through 9H-1), although some of these may be related to drilling disturbance (Emeis, Robertson, Richter, et al., 1996). Occasional diffuse zones of deformation are marked by color variation and anastomosing microdiscontinuities with millimeter-wide slip (e.g., interval 160-966A-7H-5, $42-52 \mathrm{~cm})$. Very rare clasts of limestone show evidence of tectonic brecciation, shearing, and veining (Core 160-966A-13X). Faults are most numerous near the top of the Mass-Flow Unit and near the base of the overlying lower Pliocene succession, where sediment bedding changes from tilted to horizontal (Emeis, Robertson, Richter, et al., 1996). Occasional examples of irregular anastomosing lamination parallel to bedding may be the result of tilting, slumping, and differential movement between unconsolidated to semilithified layers (Emeis, Robertson, Richter, et al., 1996).

\section{DIAGENESIS}

Macroscopically, some intervals especially near the base of the succession are partially to completely cemented by sparry calcite (e.g., Section 160-966A-7H-5). Many individual limestone clasts underwent partial dissolution before being incorporated into the MassFlow Unit (e.g., Holes 966A-7H and 9H; Figs. 10C-10F, Figs. 12A$12 \mathrm{~F})$. Rare thin layers of foraminifer sand are cemented by sparry calcite and pyrite. Intervals in the vicinity of organic-rich layers (i.e., sapropels) exhibit sulfide mobility (Core 160-966A-8H).

Study of thin sections (Figs. 10-12) shows that the micritic limestones are commonly recrystallized to microspar, with solution cavities partly filled with blocky and rhombic spar (intervals 160-966A$7 \mathrm{H}-6,86-90 \mathrm{~cm}, 966 \mathrm{C}-11 \mathrm{H}, 0-3 \mathrm{~cm}$, and 966D-9H-5, 18-20 cm). The latter is inferred to be dolomite, as also suggested by X-ray diffraction (XRD) results (see below). The micritic matrix is partly recrystallized to blocky calcite. Electron microprobe analysis of blocky spar in two samples showed that this cement is composed of lowmagnesian calcite (see Robertson, Chap. 36, this volume, for details). Shell and echinoderm fragments exhibit syntaxial fibrous overgrowths (interval 160-966C-13X-1, 10-14 cm). Reworked shallowwater carbonate grains include small patches of radiating fibrous carbonate (interval 160-966C-13X-1, 10-14 cm; Fig. 10A), locally as discrete fibrous sheaves (interval 160-966C-13X-1, 40-43 cm; Fig. 10B). Some allochems exhibit well-developed micritic envelopes, whereas others are partly or totally dissolved and partially filled with calcite spar (interval 160-966C-13X-1, 40-43 cm).

Many limestone clasts exhibit substantial solution porosity. Cavities are variably filled with blocky calcite and rhombic dolomite (e.g., interval 160-966A-7H-6, 86-90 cm). Many calcite crystals are pointed and have a scalenohedral form (e.g., interval 160-966D-12X$2,133-135 \mathrm{~cm})$. Small micritic inclusions are locally observed within the bladed spar. Solution cavities are rarely almost completely filled with sparry calcite (e.g., interval 160-966A-9H-2, 76-79 cm). Many cavities are partially lined with bladed sparry calcite (e.g., intervals $160-966 \mathrm{~B}-9 \mathrm{H}-1,0-3 \mathrm{~cm}$, and $9 \mathrm{H}-4,2-31 \mathrm{~cm}$ ).

Some small lithoclasts within the matrix recrystallized before being incorporated into a less recrystallized matrix. Small lithoclasts with abundant solution porosity have sharp angular margins against a less-altered matrix (e.g., interval 160-966B-9H-1, 0-3 cm). However, the matrix is also variably replaced by blocky spar (interval 160-966A-13X-CC, 1-4 cm). By contrast, some clasts of poorly lithified pelagic chalk show only minor solution porosity (e.g., intervals 160-966B-14X-CC, 0-18 cm, and 966C-12X-CC, 12-14 cm), with small bladed sparry calcite crystals coating cavities.

The diagenesis of the limestone clasts is similar to that of the underlying Miocene limestones (Robertson et al., Chap. 36, this volume). The extensive solution porosity probably resulted from circu- lation of meteoric waters during the Messinian. Many of the clasts clearly underwent development of secondary solution porosity before being incorporated as clasts within debris flows. The chalky clasts and the fine-grained matrix show much less evidence of solution porosity development, probably because of lack of subaerial exposure.

\section{X-RAY DIFFRACTION ANALYSIS}

Twenty samples, mainly matrix (but including some small clasts) were analyzed (Table 1). A relatively small number of samples contain aragonite, as well as calcite, or calcite, aragonite, and dolomite, or contain pyrite in addition to calcite and dolomite. Minor quartz is locally present. In addition four limestone clasts were analyzed and gave similar results (Table 1). Semiquantitative analysis of a few samples confirmed that some samples are strongly dolomitized.

\section{COMPARISON WITH ONSHORE CYPRUS}

Units comparable with the lower Pliocene Mass-Flow Unit at Site 966 are found in three areas of Cyprus: first, along the northern margin of the Troodos ophiolite (along the southern edge of the Mesaoria basin); second, associated with the Polis graben in western Cyprus; and third, as a unique channelized unit along the southeastern margin of the Troodos ophiolite (Fig. 2). Background information on the Neogene-Holocene sedimentary geology of southern Cyprus is given in Robertson et al. (1991).

\section{Northern Margin of the Troodos Ophiolite}

Matrix-supported breccias, facies similar to those of the Eratosthenes Mass-Flow Unit, are well exposed along the northern margin of the Troodos ophiolite, at the southern margin of the Mesaoria basin (Follows, 1990; Figs. 2, 13). In this area, the Troodos ophiolite is overlain by a thin (tens of meters) succession of lower Tertiary deep-water pelagic sediments (Lefkara Formation) and then by upper

Table 1. Whole-rock $\mathrm{X}$-ray diffraction data from clasts and matrix within the Mass-Flow Unit at Site 966.

\begin{tabular}{|c|c|c|}
\hline $\begin{array}{l}\text { Core, section, interval } \\
(\mathrm{cm})\end{array}$ & Constituent & $\begin{array}{l}\text { Dolomite } \\
\quad(\%)\end{array}$ \\
\hline $\begin{array}{l}\text { 160-966A- } \\
\text { 7H-6, 86-90 } \\
9 \mathrm{H}-2,28-32 \\
9 \mathrm{H}-2,76-79 \\
10 \mathrm{X}-2,45-49 \\
13 \mathrm{X}-\mathrm{CC}, 1-4\end{array}$ & $\begin{array}{l}\text { CALCITE only } \\
\text { *CALCITE, quartz, dolomite } \\
\text { CALCITE, Aragonite } \\
\text { CALCITE, Dolomite } \\
\text { CALCITE, Dolomite }\end{array}$ & $\begin{array}{l}- \\
\overline{-} \\
31\end{array}$ \\
\hline $\begin{array}{l}160-966 \mathrm{~B}- \\
9 \mathrm{H}-1,0-3 \\
9 \mathrm{H}-3,26-31 \\
9 \mathrm{H}-4,57-61 \\
9 \mathrm{H}-4,103-106 \\
12 \mathrm{X}-1,69-74 \\
16 \mathrm{X}-1,0-5\end{array}$ & $\begin{array}{l}\text { CALCITE, Dolomite, Quartz } \\
\text { CALCITE, Aragonite, Dolomite } \\
\text { CALCITE, quartz, dolomite } \\
\text { CALCITE, Aragonite } \\
\text { DOLOMITE, Calcite } \\
\text { CALCITE only }\end{array}$ & $\begin{array}{l}<5 \\
<5 \\
- \\
1 \\
-\end{array}$ \\
\hline $\begin{array}{l}160-966 \mathrm{C}- \\
11 \mathrm{H}-1,0-3 \\
13 \mathrm{X}-1,10-14 \\
15 \mathrm{X}-\mathrm{CC}, 7-10 \\
16 \mathrm{X}-\mathrm{CC}, 8-10 \\
16 \mathrm{X}-\mathrm{CC}, 27-29\end{array}$ & $\begin{array}{l}\text { CALCITE only } \\
\text { CALCITE, Aragonite } \\
\text { CALCITE, dolomite } \\
\text { DOLOMITE, calcite } \\
\text { DOLOMITE only }\end{array}$ & $\begin{array}{l}- \\
1 \\
98 \\
-\end{array}$ \\
\hline $\begin{array}{l}\text { 160-966D- } \\
\text { 9H-2, 20-22 } \\
\text { 10H-1, 102-109 } \\
10 \mathrm{H}-4,126-130 \\
10 \mathrm{H}-4,131-135 \\
12 \mathrm{X}-2,93-95 \\
15 \mathrm{X}-\mathrm{CC}, 0-5 \\
15 \mathrm{X}-\mathrm{CC}, 28-30 \\
17 \mathrm{X}-\mathrm{CC}, 0-18\end{array}$ & $\begin{array}{l}\text { CALCITE, aragonite } \\
\text { *CALCITE only } \\
\text { *CALCITE, dolomite, quartz } \\
\text { *CALCITE, dolomite } \\
\text { CALCITE, dolomite } \\
\text { CALCITE, pyrite, dolomite } \\
\text { CALCITE, dolomite } \\
\text { DOLOMITE, Calcite }\end{array}$ & $\begin{array}{l}- \\
\overline{-} \\
\overline{-} \\
\overline{78}\end{array}$ \\
\hline
\end{tabular}

Notes: Major constituent is all capital letters (e.g., DOLOMITE); minor constituent is initial capitals (e.g., Dolomite); trace constituent is all lowercase letters (e.g., dolomite). $*=$ clast; otherwise matrix was analyzed. 

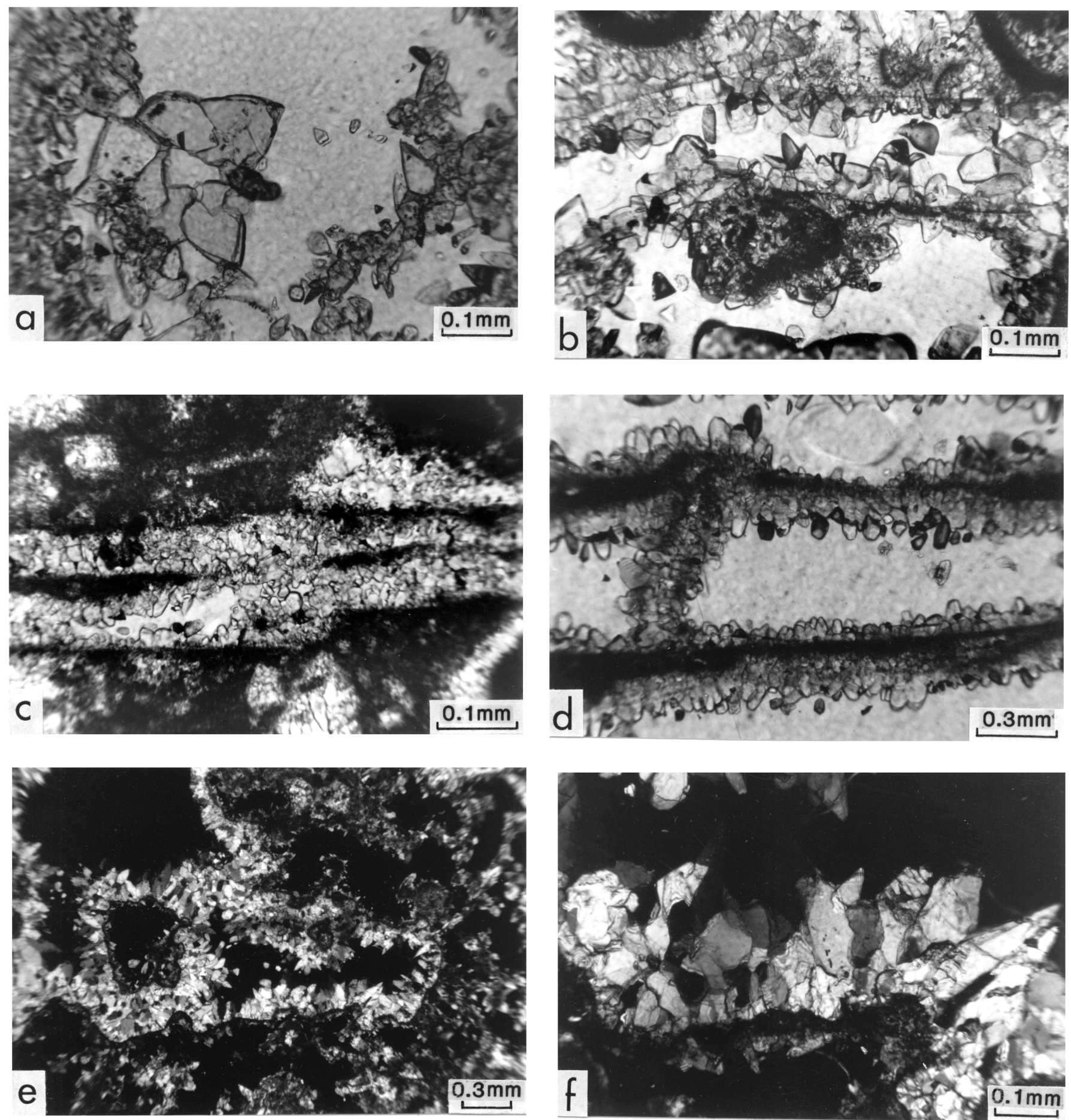

Figure 12. Photomicrographs of diagenetic features. A. Solution cavity in biomicrite, with minor fill of prismatic sparry calcite (interval 160-966D-9H-2, 20-29 $\mathrm{cm}$ ). B. Solution cavity in biomicrite, with partial fill of prismatic sparry calcite (interval 160-966D-10H-1, 102-109 cm). C. Bivalve shells, internally dissolved then partly filled with sparry calcite (interval 160-966D-10H-1, 102-109 cm). D. Detail of dissolved bivalve shell showing micritic envelope overgrown by prismatic spar (interval 160-966D-10H-1, 102-109 cm). E. Solution cavity after dissolution of a bioclast, overgrown and largely filled with calcite spar (interval 160-966A-7H-6, 86-90 cm). F. Solution cavity entirely filled with calcite spar (interval 160-966A-7H-6, $86-90 \mathrm{~cm}$ ). 
S

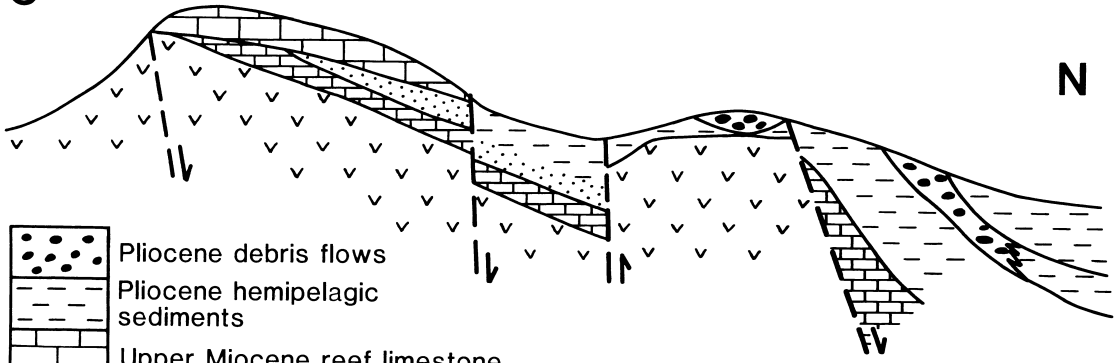

Upper Miocene reef limestone

Miocene mixed pelagic and

clastic sediments

U. Cretaceous-Miocene pelagic limestone

Basaltic extrusives of Troodos ophiolite preted in terms of gravity deposition related to active extensional faulting. See Figure 2 for location (redrawn from Follows and Robertson, 1990).

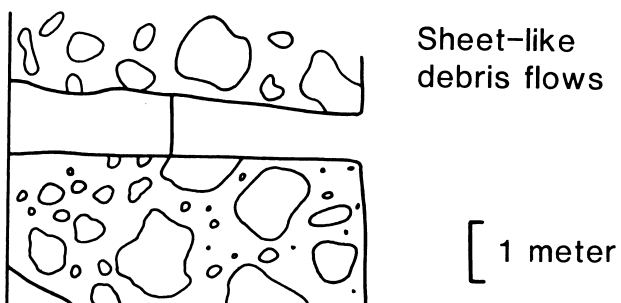

Hemipelagic

carbonate

Channelized

debris flow

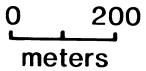

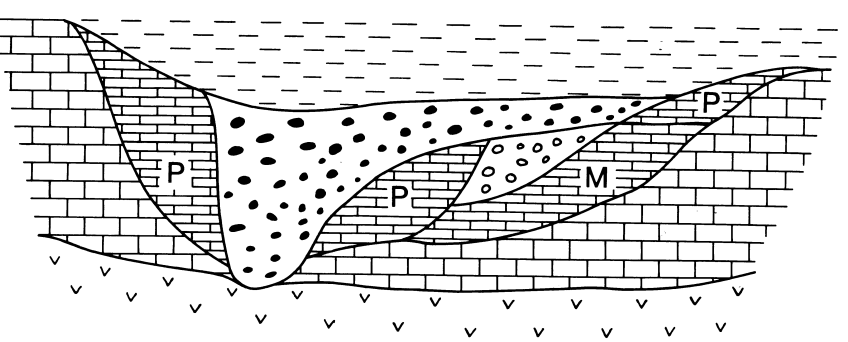

\begin{tabular}{llll} 
Lower Pliocene debris flows \\
\cline { 1 - 2 }
\end{tabular}

Figure 14. Diagram indicating the relations of lithologic units along the northern margin of the Troodos ophiolite. Note particularly the presence of talus shed from reefs in the late Miocene and the large volumes of channelized lower Pliocene carbonate debris flows that were emplaced related to contemporaneous extensional faulting (redrawn from Follows, 1990).

Miocene (Tortonian) limestones (Koronia Member of the Pakhna Formation). These limestones are mainly composed of coralline patch reefs and associated off-reef facies. Patch-reefs developed on the footwalls of rotated fault blocks, from which talus was shed into topographically lower hanging wall basins (Fig. 13; Follows and Robertson, 1990; Follows et al., 1996).

The Miocene is unconformably overlain by pink or pale-gray pelagic carbonates rich in planktonic foraminifers of early Pliocene age (Follows, 1990). Extensional faulting was active during lower Pliocene time and stratified matrix-supported debris flows were interbedded with foraminiferal carbonates (Figs. 14, 15). Blocks of shallow-water limestone (up to several meters in size) are rarely seen within a chalky matrix. In general, the lower Pliocene debris flows are very poorly sorted and texturally immature; however, they become more matrix-supported upward with more chalk and fewer granule-size clasts. Common clasts include bioclastic limestone, calcareous mudstone, angular chert, and basalt. Rarer clasts include planktonic foraminiferal grainstone with bivalve molds and calcareous algae, poritid coral, echinoids, laminated chalk, and pink micritic carbonate. Clasts mainly range in size from 0.5 to $5 \mathrm{~cm}$, but exceptionally up to tens of centimeters. The matrix is commonly white chalky marl, but includes fine- to medium-grained, friable, angular, carbonate clasts. Some of the matrix-supported layers exhibit normal grading and are interpreted as gravity flows (Figs. 12, 13).

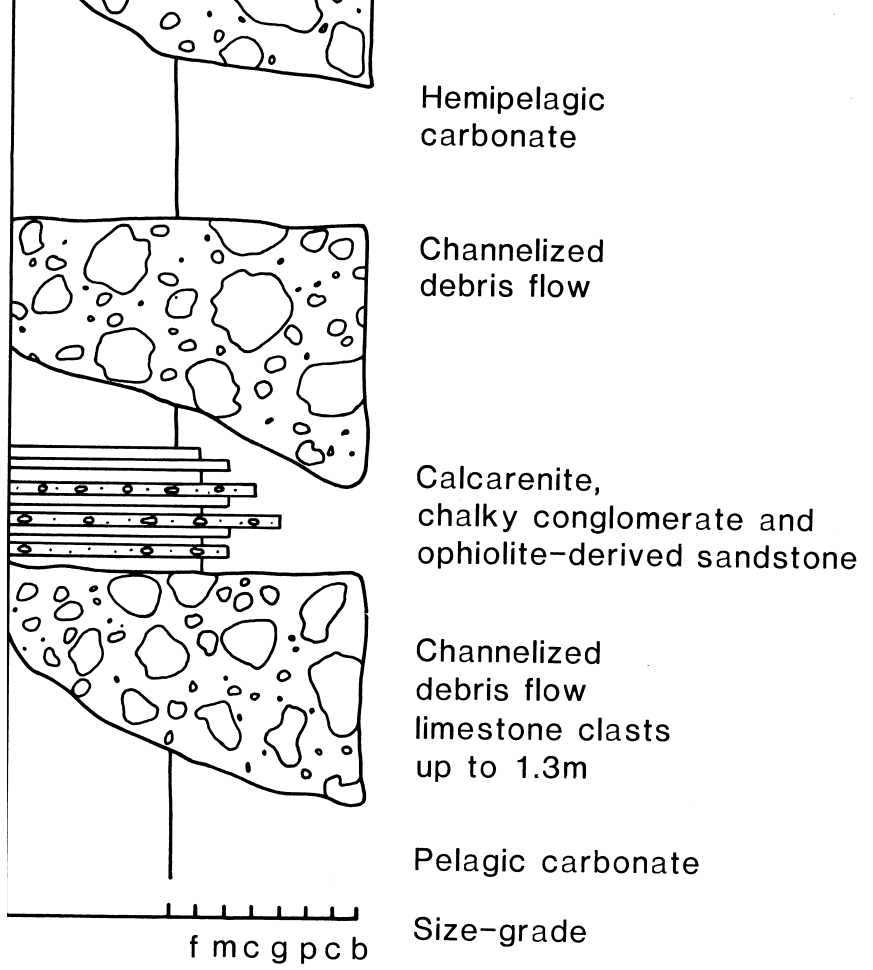

Figure 15. Log of lower Pliocene carbonate debris flows along the northern margin of the Troodos ophiolite (Mesaoria sub-basin). Note also the interbedded finer grained carbonates. Similarities exist with the Mass-Flow Unit at Site 966 (redrawn from Follows, 1990). $\mathrm{f}=$ fine grained, $\mathrm{m}=$ medium grained, $\mathrm{c}=$ coarse grained, $\mathrm{g}=$ gravel, $\mathrm{p}=$ pebble, $\mathrm{c}=$ cobble, $\mathrm{b}=$ boulder.

The matrix-supported facies pass upward into brownish mudstones, siltstones, and sandstones, containing abundant ophiolitederived sediment, typical of the overlying Nicosia Formation (McCallum, 1989; McCallum and Robertson, 1990, 1995; Fig. 13).

The lower Pliocene debris flows are both similar and dissimilar to the Site 966 Mass-Flow Unit. Similarities include (1) the presence of 
Miocene shallow-water limestone and Pliocene chalk clasts; (2) the matrix-supported nature of both; and (3) Miocene clasts in both are often highly recrystallized with well-developed solution porosity. Two differences, however, are (1) that nannofossil carbonates underlie the inferred debris flows in the Mesaoria basin, but such sediments were not cored at Site 966; and that (2) the clasts include much older, lower Tertiary sedimentary and upper Cretaceous ophiolitic material, whereas clasts at Site 966 were derived only from lower Pliocene and Miocene sediments.

\section{Polis Graben, Western Cyprus}

The approximately north-south-trending Polis graben (Fig. 2) separates the Troodos ophiolite in the east from outcrops of ophiolite (in the Akamas Peninsula) and "melange" (the Mesozoic Mamonia Complex) in the west. The Polis graben is filled with sediments of mainly Pliocene and Pleistocene age (Orszag-Sperber et al., 1987; Robertson et al., 1995a; Fig. 16). Sedimentary and structural analysis (Payne, 1995; Payne and Robertson, 1995) indicates that the graben was initially a broad sedimentary basin (i.e., Polemi sub-basin) in which Miocene pelagic chalks (i.e., Pakhna Formation), and then Messinian evaporites, accumulated. Rifting to form a relatively narrow ( 5-km wide) north-south-trending graben began during the Messinian and had effectively ended by the early Pliocene. The margins of the graben are marked by high-angle extensional faults (Fig. 2).

There is extensive evidence of subaerial exposure during the Messinian in the northern part of the Polis graben area during the Messinian salinity crisis. A pronounced relief (about $30 \mathrm{~m}$ ) developed in response to erosion, and karst surfaces were developed widely. Paleo-fault scarps are overlain by thin chalk or limestone con-

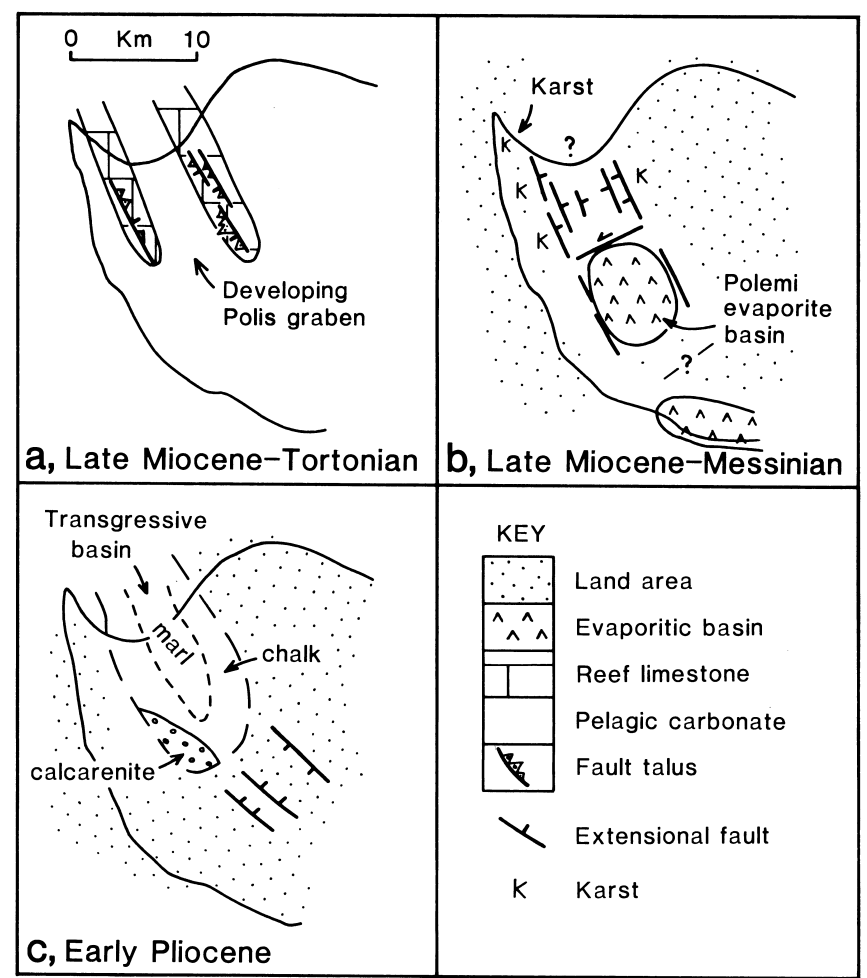

Figure 16. Paleogeographical sketch maps of the Polis graben area of western Cyprus: (A) in the late Miocene (Tortonian), showing colonization of the rift margins by fringing coral reefs; (B) during the Messinian (in the south) associated with precipitation of evaporites near the depocenter (Polemi subbasin) and karstification and erosion of the uplifted graben flanks; (C) in the early Pliocene, with passive fill of the graben by marine argillaceous sediments (simplified from Payne and Robertson, 1996). glomerates, of local fluvial and/or colluvial origin, and then transgressed by lower Pliocene pink hemipelagic carbonates with numerous planktonic foraminifers. Extensive fault-related sediments are exposed along the major eastern bounding fault of the Polis graben (e.g., near Evretou dam). These are chalk, limestone conglomerates, and limestone breccias up to several meters thick. Chalky conglomerates consist of subrounded micritic and bioclastic chalk and marl pebbles $(1-5 \mathrm{~cm}$ in size) in a matrix of smaller, rounded clasts $(2-10 \mathrm{~mm})$ of this lithology, together with micrite. The clasts were derived from underlying Miocene pelagic carbonates (Pakhna Formation). In addition, local limestone conglomerates comprise larger $(5-10 \mathrm{~cm})$ angular to subrounded clasts eroded from the upper Miocene reef limestone of the Koronia Member (Pakhna Formation), (Follows, 1990; Follows et al., 1996). Thin lenses of conglomerates with well-rounded pebbles $(<10 \mathrm{~cm})$, are interpreted as fluvial in origin. In contrast to these nonmarine Messinian sediments, the base of the Pliocene succession in the Polis graben locally includes chalky conglomerates interpreted as debris flows that are similar to those of the Eratosthenes Mass-Flow Unit (A. Payne, pers. comm., 1997).

The significance of the Polis graben area in relation to Eratosthenes Mass-Flow Unit at Site 966 derives from the following: (1) The Miocene limestones bordering the Polis graben show evidence of karstification and erosion that probably also affected Eratosthenes in the Messinian. (2) Alluvial and colluvial deposits formed locally on Messinian erosion surfaces. However, there is little evidence that this material was reworked during the Pliocene (except very locally) despite the steep relief created by the faults bounding the Polis graben. This suggests that erosion alone is unlikely to have given rise to the Eratosthenes Mass-Flow Unit. (3) Chalky debris flows did form locally in areas of high relief (generated by faulting) soon after Pliocene transgression.

\section{Pliocene Channels along the Southern Margin of the Troodos Ophiolite}

At one locality in southern Cyprus (near Khirokitia; Fig. 2), upper Miocene carbonates of the Pakhna Formation are cut by a deeply incised channel that is filled with siltstones, mudstones and redeposited conglomerates (Eaton, 1987; Eaton and Robertson, 1993; Fig. 17). Houghton et al. (1990) reported nannofossils of upper Pliocene age from muds associated with these conglomerates.

The floor of the channel is a low-angle unconformity (about $15^{\circ}$ ) with Miocene carbonates of the Pakhna Formation beneath. The channel fill comprises two main units: (1) a lower unit of relatively small, lenticular conglomerates within mainly siltstone and sandstone; and (2) an upper unit dominated by chalky material. The conglomerates in the lower unit are flat based, matrix-supported, lenticular, and up to $2.8 \mathrm{~m}$ thick. Clasts are mainly weathered basalt, diabase, and minor gabbro, and subordinate chalk, chert, and coralline limestone and calcarenite (both from the Pakhna Formation), locally as outsize clasts (i.e., "rafts" up to $2.5 \mathrm{~m}$ long) set in a matrix of softweathering sandstone and fine conglomerate (i.e., pebbly mudstone). Mudstones near the base show local evidence of large-scale slumping. Several of the conglomerate lenses also include numerous pelecypods and other macrofauna typical of the Pliocene succession elsewhere. Interbedded sandstone is friable, calcareous, and mainly medium bedded, locally with concentrations of siltstone rip-up clasts. The overlying upper unit (up to $15 \mathrm{~m}$ thick) is incised into the succession described above and is dominated by large (i.e., meter-sized) "rafts" of chalky debris.

The channel, up to $35 \mathrm{~m}$ deep and up to $80 \mathrm{~m}$ wide, becomes narrower and steeper sided to vertical southward (near Khirokitia archaeological site), but then broadens and becomes less well defined further south (i.e., south of the Limassol-Nicosia road). The channel system was incised and then progressively filled with talus derived from the sedimentary cover and upper levels of the Troodos ophiolite (Fig. 15). Material was shed into the channel mainly by mass-flow, causing dewatering and slumping of underlying marine sediments. 


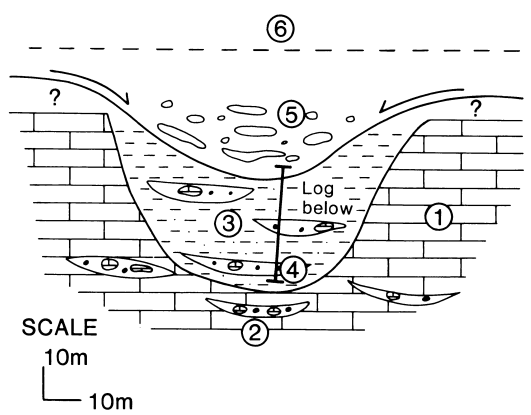

1. Late Miocene bioclastic limestones (Koronia Member)

2. Channels in Koronia Member

3. U. Pliocene silts muds and sands

4. Channels in U. Pliocene

5. Upper Pliocene chalky debris flow ( Athalassa Fm.)

6. Quaternary (eroded)

b

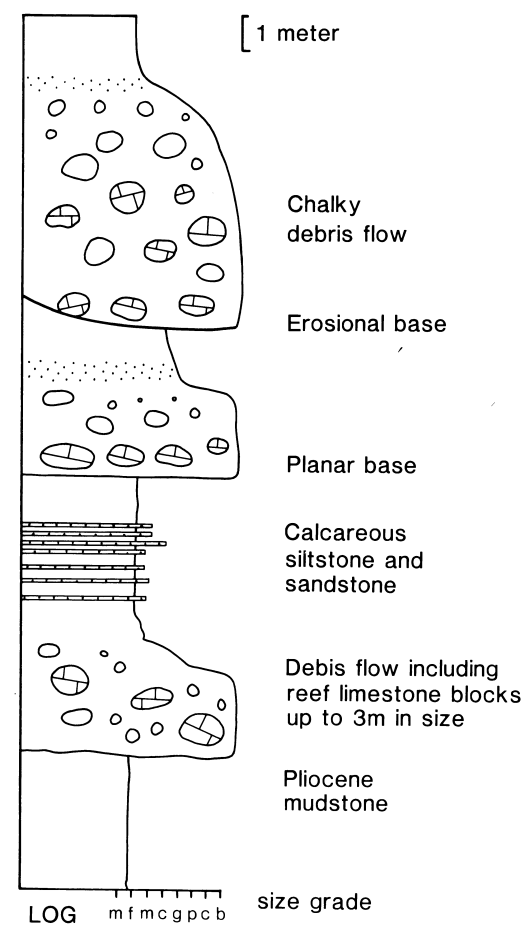

Figure 17. Upper Pliocene paleovalley in southern Cyprus. A. Log through part of the paleovalley. B. Schematic cross section of the channel. See text for further details (from A.H.F. Robertson and A.J. Poole, unpubl. data).

The channel was finally filled with chalky debris flows, correlated with the upper Pliocene Athalassa Formation.

Two possible interpretations of the paleovalley are (1) that it was cut during the Messinian sea-level drawdown, but remained free of sediment until the late Pliocene, when it began to fill; and (2) that the channel was first cut in the late Pliocene and filled later in late Pliocene time (1.85-2.35 Ma). The latter is the preferred option, as it relates to the time of strong regional uplift of the Troodos ophiolite as a whole (McCallum and Robertson, 1990). When compared with the Eratosthenes Mass-Flow Unit, there are some marked differences. (1) The mainly angular nature of the clasts at Site 966 differs strongly from clasts in the onshore channelized unit, which are more rounded. (2) The onshore channelized unit contains clasts from many different units of different ages, reflecting a large-scale channel system, whereas the Mass-Flow Unit contains clasts restricted to Miocene-Pliocene carbonates. The comparison suggests that it is unlikely that Site 966 Mass-Flow Unit resulted from subaerial erosion and redeposition within a well-defined subaqueous channel system.

\section{Florence Rise}

Upper Miocene to lower Pliocene sediments were recovered on the Florence Rise west of Cyprus at DSDP Sites 375 and 376 (Fig. 2). The recovery in both holes overlaps stratigraphically in the lowermost Pliocene, where Messinian evaporites are overlain by a very thin unit $(9 \mathrm{~cm})$ of light-brown to yellowish brown nannofossil marl containing small pieces of gray marls. These sediments are overlain by $32 \mathrm{~cm}$ of thin-bedded, medium-gray nannofossil marl, with small amounts of admixed white and brown marl. A thin disturbed unit is interpreted as a slump of early Pliocene age comprising both upper Miocene and lower Pliocene material. The succession continues upward with varicolored nannofossil marls of early to late Pliocene age (Hsü, Mondadert, et al., 1978). Slumping on the Florence Rise could relate to tectonic movements along the westward extension of the $\mathrm{Cy}$ prus active margin that could be contemporaneous with formation of the Mass-Flow Unit at Site 966.

\section{Depositional-Tectonic Models for the Eratosthenes Mass-Flow Unit}

Three alternative hypotheses for the formation setting of the Site 966 Mass-Flow Unit can be considered in the light of the onshsore Cyprus comparisons, as follows:

1. Eratosthenes was emergent in the late Miocene. Elevated reef structures in the vicinity of Site 966 gave rise to a rugged topography that was then karstified. Limestone was eroded to form talus that was then reworked in a coastal environment during early Pliocene transgression. Such reworking would allow redeposition into deeper water nannofossil ooze, as observed. In this hypothesis, only erosion and transgression are involved without tectonics (Major et al., Chap. 38, this volume). Problems with this interpretation are that subaerial karstification is associated with soil (i.e., of red terra-rossa type), as observed in the Messinian interval of Site 955 (Emeis, Robertson, Richter, et al., 1966), but this was not observed in the Mass-Flow Unit. Furthermore, clasts are rarely well rounded, as expected if extensive reworking in a highenergy, coastal setting had taken place. Also, the micritic matrix first appears relatively low in the succession (Core 160966C-15X), suggesting that shallow marine deposition was minimal. Finally, the Messinian and Pliocene interface in southern Cyprus is not associated with erosional talus except where steep relief was generated by tectonic processes.

2. Channel-fill hypothesis: The Eratosthenes Seamount was emergent during the Messinian and erosion cut deep channels that were filled with debris flows during the early Pliocene, without coeval tectonic activity. Arguments against this are that well-rounded clasts are rare, suggesting that clasts were mainly not reworked in fluvial setting. Also, clast-rich debris flows persist from the base to the top of the Mass-Flow Unit, implying that a continuous supply of coarse material was available, without evidence of progressive fill of a discrete channel. Finally, the debris flows are poorly sorted, in contrast to channel-fill units, which normally contain lenses of better sorted material.

3. Fault-related hypothesis: The Mass-Flow Unit developed in response to extensional faulting (Fig. 18). Faulting began in the Messinian (or before), when the Miocene limestone was exposed and karstified. Talus accumulated at the base of fault scarps, combined with minor fluvial reworking. Faults had relatively small offsets $(<10 \mathrm{~m})$, were numerous and were quite closely spaced (i.e., tens of meters). The Pliocene sea flooded back quickly with little reworking of talus. Some shallow- 


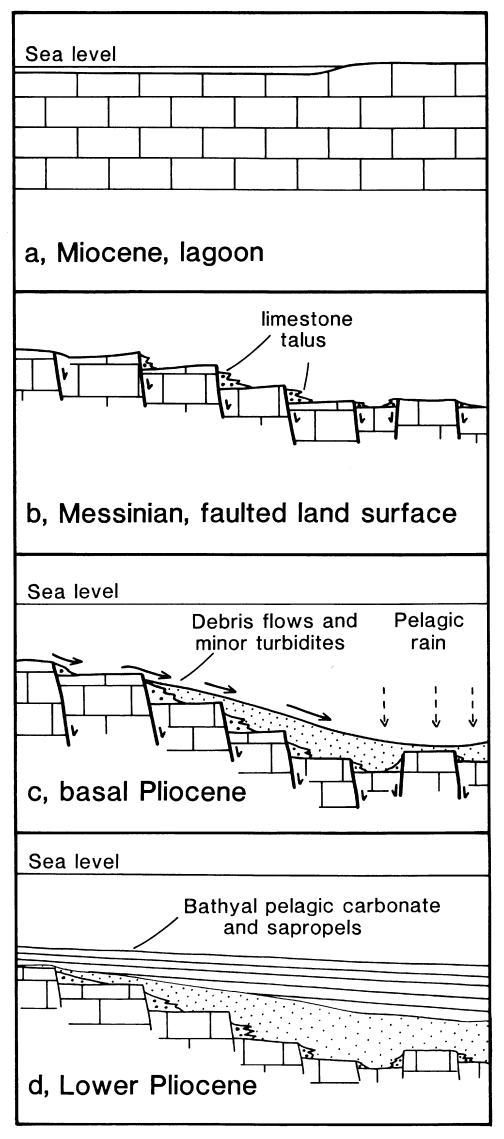

Figure 18. Fault-related genesis of the Mass-Flow Unit: (A) lagoonal setting during the Miocene; (B) Messinian exposure, weathering, and shedding of limestone talus from small fault scarps; (C) Pliocene transgression while faulting continues; talus shed into deep sea; and (D) blanketing by PliocenePleistocene deep-sea sediment. water bioclastic carbonate, however, may have accumulated during the transgression, and remained uncemented. Pliocene pelagic carbonate began to accumulate at bathyal depths. Faulting continued and may have intensified. Both the limestone talus and the newly deposited Pliocene pelagic (and minor neritic) carbonate were then reworked downslope and interbedded with bathyal pelagic carbonate and minor sapropels (Fig. 19), as multiple debris flows (Cook et al., 1972; Mullins and Cook, 1986). Clastic material continued to be shed from subaqueous fault scarps. Faulting then diminished and the area was blanketed by Pliocene pelagic carbonate, muds and sapropels. In this model, the driving mechanism was extensional tectonics (i.e., growth faulting).

Each of the three alternative interpretations is represented by different exposures in Cyprus. The comparisons suggest that only the fault-related option can readily explain all the features of the MassFlow Unit. The inferred faulting could relate to westward tilting, observed on seismic profiles, but the direction of sediment transport cannot be reliably inferred from the limited core recovery.

\section{Plate-Tectonic Model}

What caused the inferred normal faulting that led to genesis of the Mass-Flow Unit in Messinian-early Pliocene time? The Eratosthenes seamount is currently colliding with, and being thrust beneath, Cyprus along the Eurasian-African plate boundary (Cyprus active margin; Fig. 20). As a result of this collision, the seamount has experienced marked subsidence in Pliocene-Pleistocene time (Emeis, Robertson, Richter, et al., 1996; Whiting, Chap. 39, this volume). Subsidence was accentuated by the isostatic effect of loading by thick Messinian sediment $(\sim 2.5 \mathrm{~km})$ surrounding the Eratosthenes Seamount (Major et al., Chap. 38, this volume). The faulting of Eratosthenes is thus explained as the result of loading by the overriding Eurasian plate. Theoretical models indicate that initial loading results in a foreland propagating bulge, triggering uplift and erosion (Stockmal et al., 1986). However, most geological studies indicate that flexure is mainly accommodated by block faulting (Allen et al., 1986), especially where zones of inherited structural weakness are present in

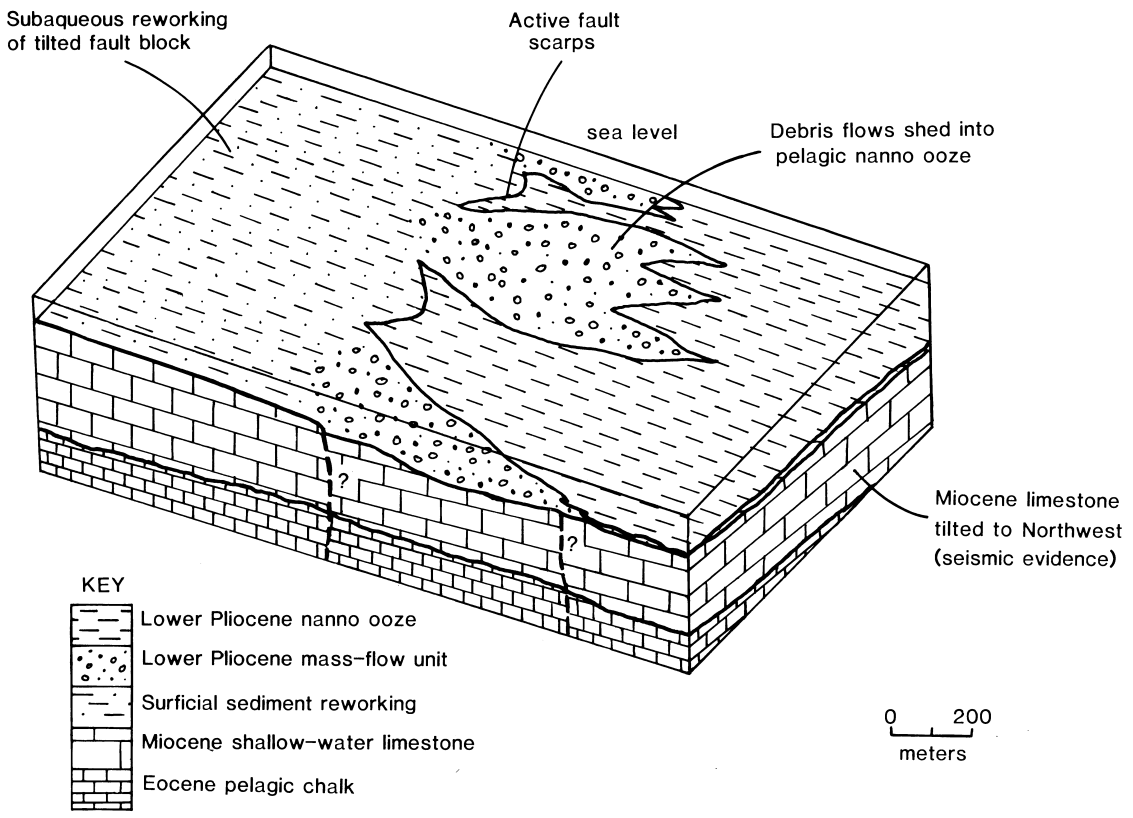

Figure 19. Interpretative block diagram showing the suggested mode of deposition of the Mass-Flow Unit during the early Pliocene, after transgression at the end of the Messinian. The direction of sediment trans port is unknown, based on the limited core recovery, but may be related to westward tilt of the Miocene interval noted on seismic profiles (Emeis, Robertson, Richter, et al., 1996, p.162). See text for discussion. 


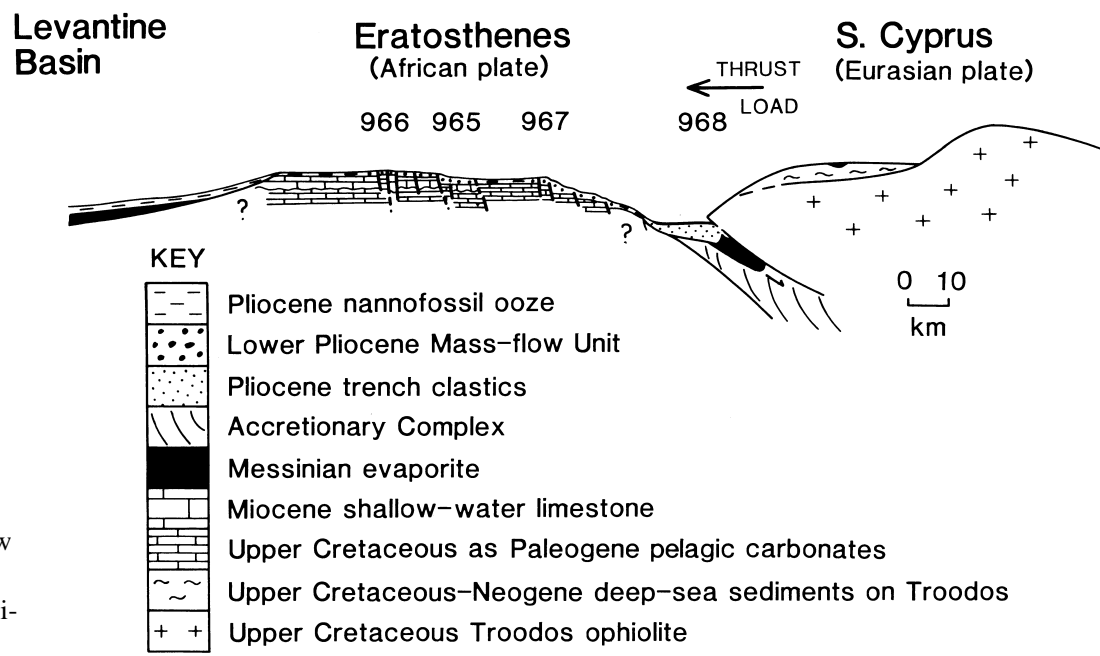

Figure 20. Plate tectonic model for formation of the Mass-Flow Unit showing the inferred tectonic setting of the Eratosthenes Seamount in the early Pliocene, during the initial stages of collision with the Cyprus active margin. oozes began to accumulate. Faulting continued, and both limestone talus and pelagic carbonate were reworked as subaqueous debris flows. The faulting is attributed to the effect of flexural loading by the Eurasian active margin to the north, as the Eratosthenes Seamount approached the trench. The Mass-Flow Unit thus records the initial stages of continental collision in this area.

\section{ACKNOWLEDGMENTS}

\section{CONCLUSIONS}

The Eratosthenes Seamount was exposed, subaerially eroded, and probably karstified during the Messinian salinity crisis, when largescale meteoric water diagenesis also took place. Clasts of limestone in the lower Pliocene Mass-Flow Unit exhibit meteoric water diagenesis. Rare well-rounded limestone clasts near the base of Mass-Flow Unit were possibly derived from the Messinian land surface.

The Eratosthenes Seamount was submerged in early Pliocene time, ushering in pelagic carbonate deposition. Minor quartzose silt was possibly of wind-blown origin.

Miocene shallow-water limestone material was eroded and reworked, mainly as debris flows within nannofossil ooze. Some of the limestone material was possibly initially derived by subaerial erosion during the Messinian and reworked into a marine setting during the early Pliocene. However, most of the limestone clasts were probably derived after the transgression when Miocene limestones were exposed on the seafloor and underwent mass wasting. Pelagic carbonate was also reworked downslope by mass-movement and was variably mixed with limestone clasts. En masse downslope movement continued after initial deposition, giving rise to interstratal soft-sediment shearing.

With time, exposed scarps were largely blanketed by pelagic carbonate. However, continuing tectonic instability gave rise to chalky debris flows higher in the succession. Miocene limestone was still available as small angular limestone clasts. After debris flow deposition ended, the seafloor still remained unstable, conducive to slumping. By then it was more level, allowing overlying lower Pliocene and Pleistocene sediments to accumulate.

Comparison with outcrops in Cyprus suggest that a fault-related origin of the Mass-Flow Unit is likely. In this interpretation, faulting began in the Messinian (or earlier), creating a rugged land surface with localized limestone talus. After Pliocene transgression, pelagic
The assistance of the master, crew, and marine technicians, in particular, on the JOIDES Resolution is acknowledged, with thanks. The manuscript benefited from comments by A. Payne and an anonymous reviewer.

\section{REFERENCES}

Allen, P.A., Homewood, P., and Williams, G.D., 1986. Foreland basins: an introduction. In Allen, P.A., and Homewood, P. (Eds.), Foreland Basins. Spec. Publ. Int. Assoc. Sedimentol., 8:3-14. thonous carbonate debris flows at Devonian bank ("reef") margins Alberta, Canada. Bull. Can. Pet. Geol., 20:439-497.

Eaton, S., 1987. The sedimentology of Mid-Late Miocene carbonates and evaporites in southern Cyprus [Ph.D. thesis]. Univ. of Edinburgh.

Eaton, S., and Robertson, A.H.F., 1993. The Miocene Pakhna Formation, Cyprus, and its relationship to the Neogene tectonic evolution of the Eastern Mediterranean. Sediment. Geol., 86:273-296.

Emeis, K.-C., Robertson, A.H.F., Richter, C., et al., 1996. Proc. ODP, Init. Repts., 160: College Station, TX (Ocean Drilling Program).

Follows, E.J., 1990. Sedimentology and tectonic setting of Miocene reef and related sediments in Cyprus [Ph.D. thesis]. Univ. Edinburgh.

Follows, E.J., and Robertson, A.H.F., 1990. Sedimentology and structural setting of Miocene reefal limestones in Cyprus. In Malpas, J., Moores, E.M., Panayiotou, A., and Xenophontos, C. (Eds.), Ophiolites: Oceanic Crustal Analogues: Nicosia, Cyprus (Geol. Surv. Dep., Minist. Agric. Nat. Resour.), 207-216.

Follows, E.J., Robertson, A.H.F., and Scoffin, T.P., 1996. Tectonic controls of Miocene reefs and related carbonate facies in Cyprus. In Fransen, E.K., Esteban, M., Ward, W.C., and Rouchy, J.-M. (Eds.), Models for Carbonate Stratigraphy from Miocene Reef Complexes of Mediterranean Regions. Concepts Sedimentol. Paleontol., 5:295-316.

Houghton, S.D., Jenkins, D.G., Xenophontos, C., and Gass, I.G., 1990. Microfossil evidence for a latest Pliocene ages for Amathus and Khirokitia channel deposits, southern Cyprus, and thereby the unroofing of the Troodos Massif. In Malpas, J., Moores, E.M., Panayiotou, A., and Xeno-
Cook, H.E., McDaniel, P.N., Mountjoy, E.W., and Pray, L.C., 1972. Alloch- 
phontos, C. (Eds.), Ophiolites: Oceanic Crustal Analogues. Proc. Symp. "Troodos 1987": Nicosia, Cyprus (Geol. Surv. Dep., Minist. Agric. Nat. Resour.), 231-234.

Hsü, K.J., Montadert, L., et al., 1978. Init. Repts. DSDP, 42 (Pt. 1): Washington (U.S. Govt. Printing Office).

Kempler, D., 1994. Tectonic patterns in the easternmost Mediterranean [Ph.D. thesis]. Hebrew Univ.

Limonov, A.F., Woodside, J.M., and Ivanov, M.K. (Eds.), 1994. Mud Volcanism in the Mediterranean and Black Seas and Shallow Structure of the Eratosthenes Seamount. Initial Results of the Geological and Geophysical Investigations during the Third "Training-through-Research" Cruise of the R/V Gelendzhik (June-July 1993). UNESCO Rep. Mar. Sci., 64.

McCallum, J.E., 1989. Sedimentation and tectonics of the Plio-Pleistocene of Cyprus [Ph.D. thesis]. Univ. of Edinburgh.

McCallum, J.E., and Robertson, A.H.F., 1990. Pulsed uplift of the Troodos Massif: evidence from the Plio-Pleistocene Mesaoria Basin. In Malpas, J., Moores, E.M., Panayiotou, A., and Xenophontos, C. (Eds.), Ophiolites: Oceanic Crustal Analogues. Proc. Symp. "Troodos 1987": Nicosia, Cyprus (Geol. Surv. Dep., Minist. Agric. Nat. Resour.), 217-229.

1995. Sedimentology of two fan-delta systems in the PliocenePleistocene of the Mesaoria Basin, Cyprus. Sediment. Geol., 98:215-244.

Mullins, H.T., and Cook, H.E., 1986. Carbonate apron models. Alternatives to the submarine fan model for paleoenvironmental analysis and hydrocarbon exploration. Sediment. Geol., 48:37-79.

Orszag-Sperber, F., Rouchy, J.-M., and Elion, P., 1989. The sedimentary expression of regional tectonic events during the Miocene Pliocene transition in the southern Cyprus basins. Geol. Mag., 126:291-299.

Payne, A.S., 1995. The tectonic and sedimentary evolution of the Polis graben system, West Cyprus [Ph.D. thesis]. Univ. of Edinburgh.

Payne, A.S., and Robertson, A.H.F., 1995. Neogene supra-subduction zone extension in the Polis graben system, West Cyprus. J. Geol. Soc. London, 153:613-628.

Robertson, A.H.F., Eaton, S., Follows, E.J., and McCallum, J.E., 1991. The role of local tectonics versus global sea-level change in the Neogene evolution of the Cyprus active margin. In Macdonald, D.I.M. (Ed.), Sedimentation, Tectonics and Eustacy Sea-level Changes at Active Margins. Spec. Publ. Int. Assoc. Sedimentol., 12:331-369.
Robertson, A.H.F., Eaton, S.E., Follows, E.J., and Payne, A.S., 1995a. Sedimentology and depositional processes of Miocene evaporites from Cyprus. Terra Nova, 7:233-254.

Robertson, A.H.F., Emeis, K.-C. (Co-Chief Scientists), Richter, C. (Staff Scientist), Blanc-Valleron, M.-M., Bouloubassi, I., Brumsack, H.J., Cramp, A., Di Stefano, G.J., Flecker, R., Frankel, E., Howell, M.J., Janecek, T.R., Jurado-Rodriguez, M.-J., Kemp, A.E.S., Koizumi, I., Kopf, A., Major, C.O., Mart, Y., Pribnow, D.F.C., Rabaute, A., Roberts, A.P., Rullkötter, J.H., Sakamoto, T., Spezzaferri, S., Staerker, T.S., Stoner, J.S., Whiting, B.M., and Woodside, J.M., 1995b. Evidence of collisional processes associated with ophiolite obduction in the Eastern Mediterranean: results of Ocean Drilling Program Leg 160. Geol. Today, Geol. Soc. Am., 11:213.

Robertson, A.H.F., Kidd, R.B., Ivanov, M.K., Limonov, A.F., Woodside, J.M., Galindo-Zaldivar, J., and Nieto, L., 1994. Probing continental collision in the Mediterranean Sea. Eos, 75:233.

Robertson, A.H.F., Kidd, R.B., Ivanov, M.K., Limonov, A.F., Woodside, J.M., Galindo-Zaldivar, J., Nieto, L., and the Scientific Party of the 1993 TTR-3 Cruise, 1995c. Eratosthenes Seamount, easternmost Mediterranean: evidence of active collapse and underthrusting beneath the Cyprus active margin. Terra Nova, 7:254-264.

Stockmal, G.S., Beaumont, C., and Boutilier, R., 1986. Geodynamic models of convergent margin tectonics: transition from a rifted margin to overthrust belt and consequences for foreland-basin development. $A A P G$ Bull., 70:181-190.

Theodoridis, S., 1984. Calcareous nannofossil biozonation of the Miocene and revision of the helicoliths and discoasters. Utrecht Micropaleontol. Bull., 32:1-271.

Date of initial receipt: 5 February 1997

Date of acceptance: 24 June 1997

Ms 160SR-038 